N evada

Environmental

Restoration

Project

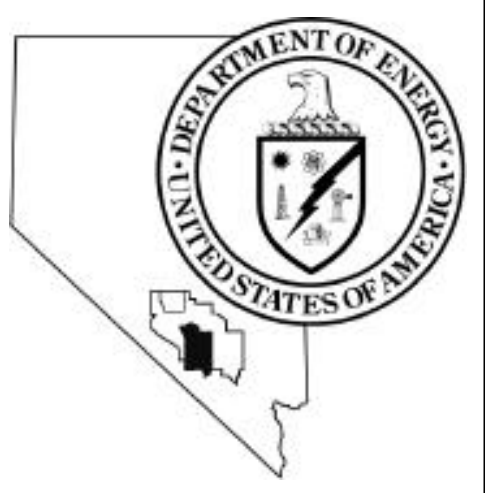

Stream lined Approach for

Environmental Restoration W ork Plan for

Corrective Action Unit 329 :

Area 22 Desert Rock Airstrip Fuel Spill

$\mathrm{N}$ evada Test $\mathrm{S}$ ite, $\mathrm{N}$ evada

Controlled Copy N $0 .:$

Revision N 0.: 0

September 1999

Approved for public release; further dissemination is unlimited.

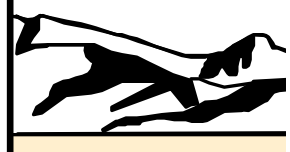

Environm ental Restoration

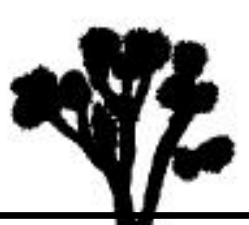

Division 
Available to the public from -

U.S. Department of Commerce

National Technical Information Service

5285 Port Royal Road

Springfield, VA 22161

(703) 487-4650

Available electronically at http://www.doe.gov/bridge . Available to U.S. Department of Energy and its contractors in paper from -

U.S. Department of Energy

Office of Scientific and Technical Information

P.O. Box 62

Oak Ridge, TN 37831-0062

(423) 576-8401

Reference herein to any specific commercial product, process, or service by trade name, trademark, manufacturer, or otherwise, does not necessarily constitute or imply its endorsement, recommendation, or favoring by the United States Government or any agency thereof or its contractors or subcontractors. 


\title{
STREAMLINED APPROACH FOR ENVIRONMENTAL RESTORATION WORK PLAN FOR CORRECTIVE ACTION UNIT 329: AREA 22 DESERT ROCK AIRSTRIP FUEL SPILL NEVADA TEST SITE, NEVADA
}

\author{
DOE Nevada Operations Office \\ Las Vegas, Nevada
}

Controlled Copy No.:

Revision No.: 0

September 1999

Approved for public release; further dissemination is unlimited. 


\section{STREAMLINED APPROACH FOR ENVIRONMENTAL RESTORATION WORK PLAN FOR CORRECTIVE ACTION UNIT 329: \\ AREA 22 DESERT ROCK AIRSTRIP FUEL SPILL NEVADA TEST SITE, NEVADA}

Approved by:

Date: $9 / 28 / 99$

Janet Appenzeller-Wing, Project Manager

Industrial Sites Project

Approved by: Signature Approved

Date: $\quad 9 / 28 / 99$

Runore C. Wycoff, Division Director

Environmental Restoration Division 


\section{Table of Contents}

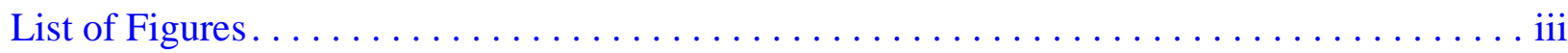

List of Tables. . . . . . . . . . . . . . . . . . . . . . . . . .

List of Acronyms and Abbreviations $\ldots \ldots \ldots \ldots \ldots \ldots \ldots \ldots \ldots \ldots \ldots \ldots \ldots \ldots \ldots \ldots \ldots \ldots$

Executive Summary . . . . . . . . . . . . . . . . . . . . . . . . . ES-1

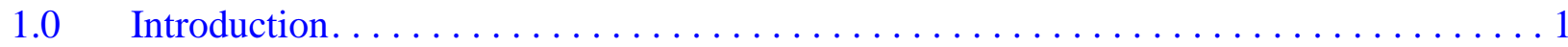

$2.0 \quad$ Unit Description and Closure Objectives $\ldots \ldots \ldots \ldots \ldots \ldots \ldots \ldots \ldots \ldots \ldots \ldots \ldots \ldots$

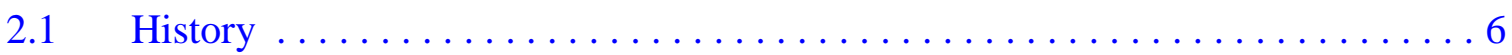

2.2 Site Location and Description. . . . . . . . . . . . . . . . . . 7

2.3 Process Knowledge. . . . . . . . . . . . . . . . . . . . 7

2.4 Closure Standards . . . . . . . . . . . . . . . . . . . . . . . . . 9

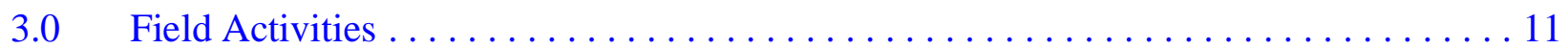

3.1 Contaminants of Potential Concern $\ldots \ldots \ldots \ldots \ldots \ldots \ldots \ldots \ldots \ldots \ldots \ldots$

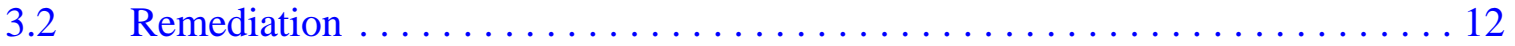

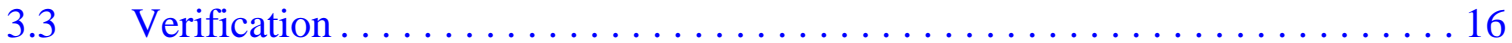

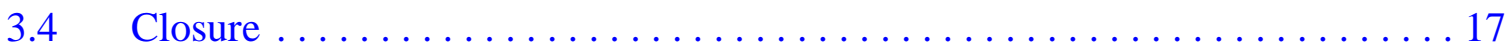

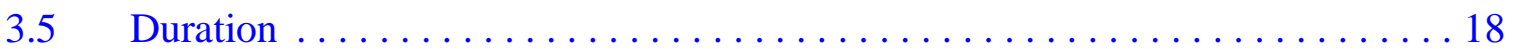

$4.0 \quad$ Reports and Records Availability . . . . . . . . . . . . . . . . . . . . . 19

5.0 Investigation/Remediation Waste Management . . . . . . . . . . . . . . . . . 20

$5.1 \quad$ Waste Minimization . . . . . . . . . . . . . . . . . . . . . . 20

$5.2 \quad$ Potential Waste Streams . . . . . . . . . . . . . . . . . . . . . . 21

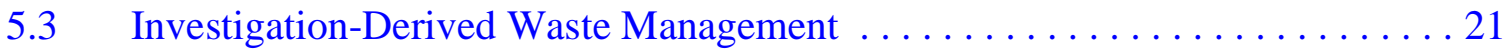

5.3 .1 Sanitary Waste . . . . . . . . . . . . . . . . . . 21

5.3 .2 Hydrocarbon Waste ... . . . . . . . . . . . . . . . . . . 21

5.3 .3 Hazardous Waste ............................ 21

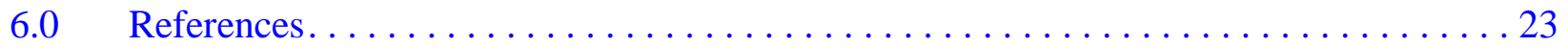

\section{Appendix A - Data Quality Objectives}

A.1.0 Introduction. . . . . . . . . . . . . . . . . . . . . . . . . . .

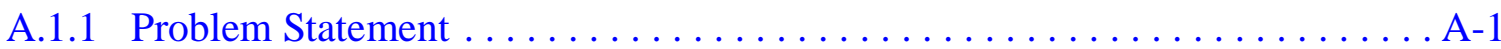

A.2.0 Conceptual Model. . . . . . . . . . . . . . . . . . . . . . . .

A.3.0 Potential Contaminants . . . . . . . . . . . . . . . . . . . . . . . . . . . . . . . A-6 


\section{Table of Contents (Continued)}

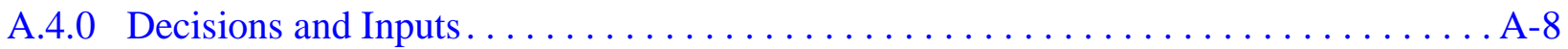

A.4.1 Decisions............................. A 8

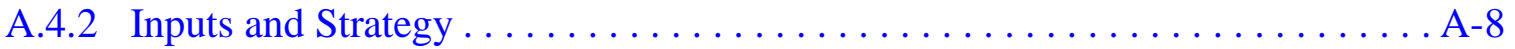

A.5.0 Investigation Strategy . . . . . . . . . . . . . . . . . . . . A-11

A.6.0 Decision Rules . . . . . . . . . . . . . . . . . . . . . . A-13

A.7.0 Decision Error. . . . . . . . . . . . . . . . .

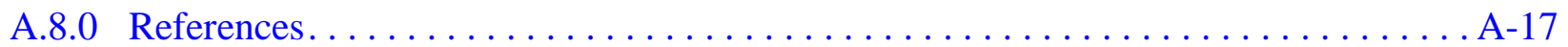

Appendix B - Project Organization

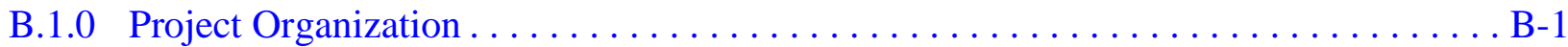

\section{Appendix C - Response to NDEP Comments}




\section{List of Figures}

Number

1-1 Corrective Action Unit 329, Area 22 Desert Rock Airstrip Fuel Spill

Site Location Map, Nevada Test Site . . . . . . . . . . . . . . . . . . . 2

1-2 Corrective Action Unit 329 Decision Logic Diagram. . . . . . . . . . . . . 4

2-1 Corrective Action Unit 329 Site Map Showing Location of

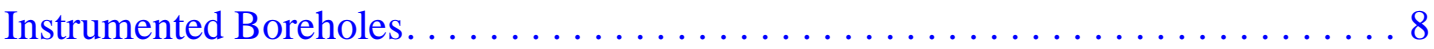




\section{List of Tables}

Number

3-1 CAU 329 Fuel Storage Area Contaminants of Potential Concern . . . . . . . . . 12

3-2 CAU 329 Investigation-Specific Decision Points and Rules . . . . . . . . . 15

A.1-1 DQO Kickoff Meeting Participants. ....................... A-2

A.2-1 Conceptual Model Element Descriptions . . . . . . . . . . . . . . . . . . . A-4

A.3-1 CAU 329 Fuel Storage Area Contaminants of Potential Concern . . . . . . . . . . A-7

A.4-1 Decisions, Inputs, and General Strategies . . . . . . . . . . . . . . . . . . A-9

A.6-1 CAU 329 Investigation-Specific Decision Points and Rules . . . . . . . . . . . A A-14 


\section{List of Acronyms and Abbreviations}

\begin{tabular}{|c|c|}
\hline bgs & Below Ground Surface \\
\hline CAS & Corrective Action Site \\
\hline CAU & Corrective Action Unit \\
\hline $\mathrm{COC}$ & Contaminant(s) of concern \\
\hline COPC & Contaminant(s) of potential concern \\
\hline $\mathrm{CR}$ & Closure Report \\
\hline DOE & U.S. Department of Energy \\
\hline $\mathrm{DOE} / \mathrm{NV}$ & U.S. Department of Energy, Nevada Operations Office \\
\hline DOT & U.S. Department of Transportation \\
\hline DQO & Data Quality Objective(s) \\
\hline DRA & Desert Rock Airport \\
\hline EPA & U.S. Environmental Protection Agency \\
\hline FFACO & Federal Facility Agreement and Consent Order \\
\hline FSL & Field-screening level(s) \\
\hline $\mathrm{ft}$ & Foot (feet) \\
\hline gal & Gallon(s) \\
\hline IDW & Investigation-derived waste \\
\hline ISMO & In Situ Monitoring of Organics \\
\hline $\mathrm{mg} / \mathrm{kg}$ & Milligram(s) per kilogram \\
\hline NDEP & Nevada Division of Environmental Protection \\
\hline NEPA & National Environmental Policy Act \\
\hline NTS & Nevada Test Site \\
\hline PAL & Preliminary action level(s) \\
\hline PPE & Personal protective equipment \\
\hline ppm & Part(s) per million \\
\hline RCRA & Resource Conservation and Recovery Act \\
\hline
\end{tabular}




\section{List of Acronyms and Abbreviations (Continued)}

SAFER Streamlined Approach for Environmental Restoration

SSHASP Site-specific Health and Safety Plan

SVOC Semivolatile organic compound(s)

THC Total hydrocarbon concentration

TPH Total petroleum hydrocarbon(s)

UST Underground Storage Tank

VOC Volatile organic compound(s) 


\section{Executive Summary}

This plan addresses characterization and closure of Corrective Action Unit 329 identified in the Federal Facility Agreement and Consent Order (FFACO, 1996). The Corrective Action Unit consists of one Corrective Action Site 22-44-01, Fuel Spill, which is the area contaminated by spills from an underground fuel storage tank formerly located at the Nevada Test Site Area 22 Desert Rock Airstrip.

This plan provides the methodology for sampling the contaminated soil-gas and soil to determine what activities, if any, are required for closure of the site. Based on an In Situ Monitoring of Organics report (REECo, 1991), the spill is localized and appears to be degrading by biological action. In addition, there is sufficient process knowledge of the tank's historical use to recommend closure of Corrective Action Unit 329 using the Streamlined Approach for Environmental Restoration process (FFACO, 1996).

The Desert Rock Airstrip consisted of the single runway, several portable buildings, two underground tanks storing jet fuel, and plumbing to several refueling areas on the ramp. The 25,000-gallon tank, 22-DRA-3, was installed in 1980 and was the only tank to have a recorded leak. The tank was bedded in sand and gravel; the base of the tank was 16 feet below the surface. Three spills (over 18,000 gallons) of jet fuel were recorded at this tank from 1985 to 1989 . The spills occurred from a pump connected to the tank that contained aviation fuel (JP-4, JP-5, and Jet-A); therefore, the constituents of potential concern are volatile organic compounds, semivolatile organic compounds, and petroleum hydrocarbons as JP-4 for soil and soil-gas.

On January 27, 1994, the tank was removed and connecting piping was left at the surface and is capped and locked. At this time, samples were collected from four different locations around the excavation. The results of the analysis of these samples ranged from 1,780 milligrams per kilogram (mg/kg) to $2,360-\mathrm{mg} / \mathrm{kg}$ total petroleum hydrocarbons as gasoline and less than $10-\mathrm{mg} / \mathrm{kg}$ total petroleum hydrocarbons as diesel.

Corrective Action Unit 329 consists of hydrocarbon-contaminated soil; therefore, closure of this site will be accomplished by verifying that the residual soil contamination is undergoing natural 
attenuation and is not migrating. It is anticipated that soil-gas and soil samples will support this assumption. Specifically, the following activities will be performed:

- Sample soil-gas from existing soil-gas sample points to determine current site conditions. Samples will be field screened for volatile organic compounds, oxygen, carbon dioxide, and methane.

- Sample soil from near the center of the spill to a depth not exceeding 200 feet for total petroleum hydrocarbons as JP-4, total volatile organic compounds, and total semivolatile organic compounds.

- Sample soil-gas from near the center of the spill for total petroleum hydrocarbons as JP-4, total volatile organic compounds, and total semivolatile organic compounds.

- Sample soils from near the center of the spill for geotechnical and microbial analyses.

- If administrative controls are necessary, use existing soil-gas sample points from borehole DRA-3. If the points are unusable, install soil-gas sample points at appropriate depths below the ground surface as determined during the investigation and approved by the U.S. Department of Energy, Nevada Operations Office and the Nevada Division of Environmental Protection. If administrative controls are not necessary, the existing soil-gas sample points will be removed if required by the U.S. Department of Energy, Nevada Operations Office or the Nevada Division of Environmental Protection.

Closure is expected to be in-place with administrative controls. On completion of the field activities, a closure report will be prepared and submitted to the Nevada Division of Environmental Protection for review and approval. 


\subsection{Introduction}

This plan addresses characterization and closure of Corrective Action Unit (CAU) 329, Area 22 Desert Rock Airstrip Fuel Spill, identified in the Federal Facility Agreement and Consent Order (FFACO, 1996). The site is located at the Nevada Test Site (NTS) Area 22 Desert Rock Airstrip (DRA) (Figure 1-1). The CAU consists of one Corrective Action Site (CAS) 22-44-01, Fuel Spill.

The CAS area is contaminated by fuel spills from the underground storage tank (UST) 22-DRA-3. The tank was emptied and removed by January 1994 and soil samples were collected as required by federal UST regulations (40 Code of Federal Regulations [CRF] Part 280) (CFR, 1998i) and state UST regulations (Nevada Administrative Code [NAC] 459.9921-.999) (NAC, 1998b). Those samples indicate the presence of hydrocarbons in soil that exceed the State of Nevada action levels (NAC 445A.2272 and NAC 459.9973) (NAC, 1998a and 1998b). To date, there has been no formal environmental site characterization performed at this CAS. This plan provides the methodology for sampling contaminated soil and soil-gas to determine what activities, if any, are required for closure of the site under regulatory compliance.

A research study consisting of near-surface and subsurface soil gas sampling was performed at this site from 1988 to 1990. Based on the In Situ Monitoring of Organics (ISMO) report (REECo, 1991), the spill is localized and appears to be degrading by biological action. The study was able to estimate, through the use of soil gas sampling, the lateral and vertical extent of the spill, allowing calculation of the approximate volume of contaminated soil. The study concluded that it is very unlikely that the underground water supply has or will be affected by these spills. In addition, there were high levels of carbon dioxide detected above the release which indicate that the spill is undergoing biological degradation. An evaluation, as required by NAC 459.9973 (1) (a-k) criteria (NAC, 1998b) when soil action levels are exceeded, can be determined based on historical site information/process knowledge. However, the Data Quality Objectives (DQO) process has identified the need for sampling using the analytical test method 8015 of the U.S. Environmental Protection Agency (EPA) that is modified for petroleum hydrocarbons, as well as additional information on current site conditions. 


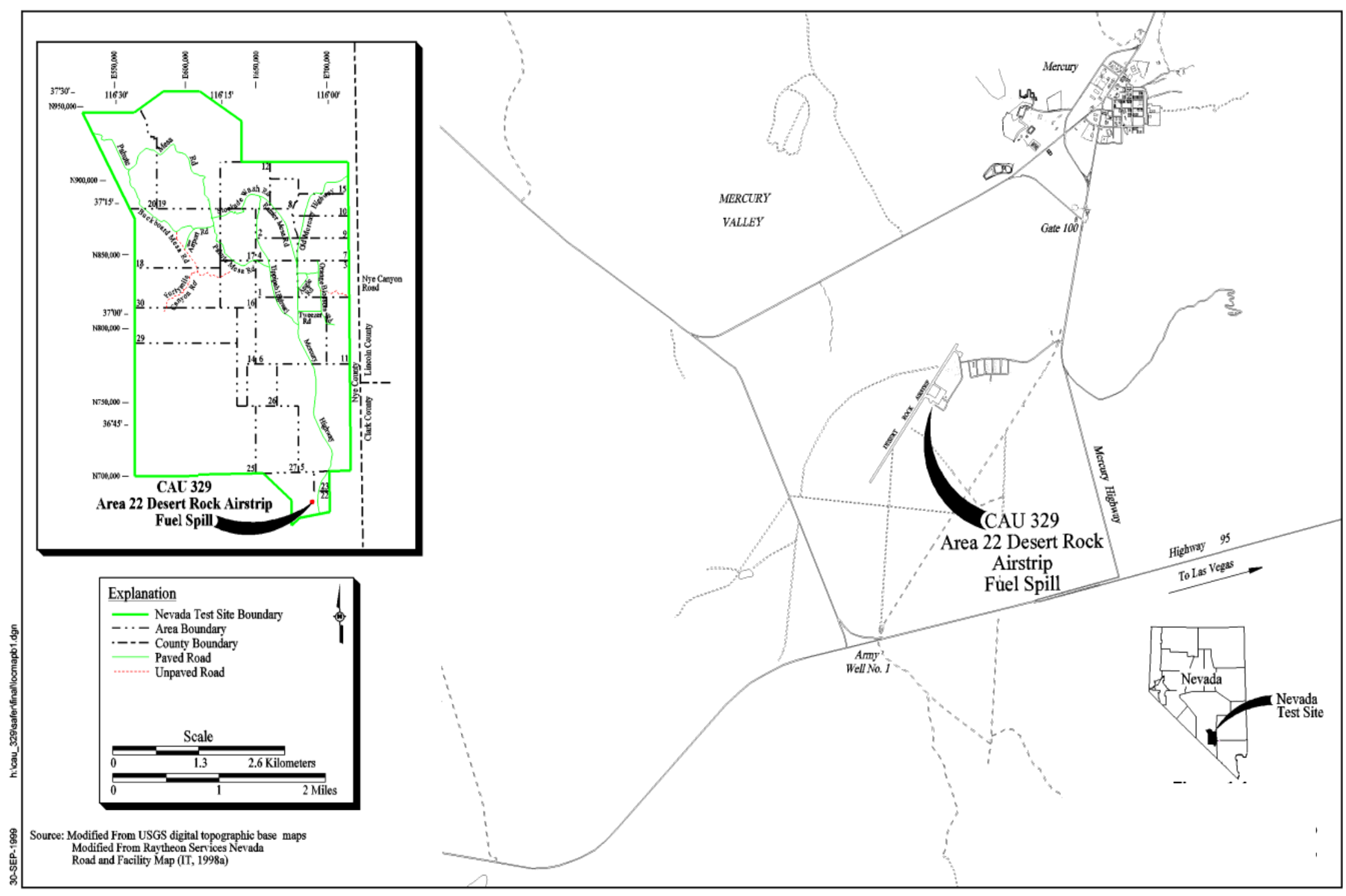

Figure 1-1

Corrective Action Unit 329, Area 22 Desert Rock Airstrip Fuel Spill Site Location Map, Nevada Test Site 
There is sufficient process knowledge of the tank's historical use and knowledge of the contaminants of potential concern (COPCs) to recommend closure of CAU 329 using the Streamlined Approach for Environmental Restoration (SAFER) process (FFACO, 1996).

The SAFER process combines elements of the DQO process and the observational approach to help plan and conduct corrective actions. DQOs are used to identify the problem and define the type and quality of data needed to complete the investigation phase of the process. The observational approach provides a framework for managing uncertainty and planning decision making. The purpose of the investigation in the SAFER process is to verify the adequacy of existing information to implement the corrective action.

The SAFER concept recognizes that technical decisions may be made based on incomplete but sufficient information, as well as the experience of the decision-maker. Uncertainties are addressed through documented assumptions that are verified by sampling and analyses, data evaluation, on-site observations as planned activities progress, and developing any necessary contingency and monitoring plans. The remediation and closure may proceed simultaneously with site characterization as sufficient data are gathered to confirm or disprove the assumptions made in selecting the closure method. If at any time during site closure, new information is developed that indicates that the closure method should be revised, the closure activities will be redirected to more appropriately protect human health and the environment.

The decision process for closure of CAU 329 is summarized in Figure 1-2. This decision process starts with the evaluation of the existing borehole DRA-3 soil-gas sample points. The process will continue with sampling of the soil near the contaminant center-of-mass via a borehole, and closure of the site based on the soil-gas and soil samples. Closure will be based on an evaluation of NAC 459.9973 (1) factors. Closure in-place with administrative controls and soil-gas sampling/monitoring from DRA-3 or new sample points will be considered.

The following will complete closure of CAU 329:

- Sample soil-gas from near the center of the spill and surrounding locations near the spill. Field screen the soil-gas for volatile organic compounds (VOCs), oxygen $\left(\mathrm{O}_{2}\right)$, carbon dioxide $\left(\mathrm{CO}_{2}\right)$, and methane. 


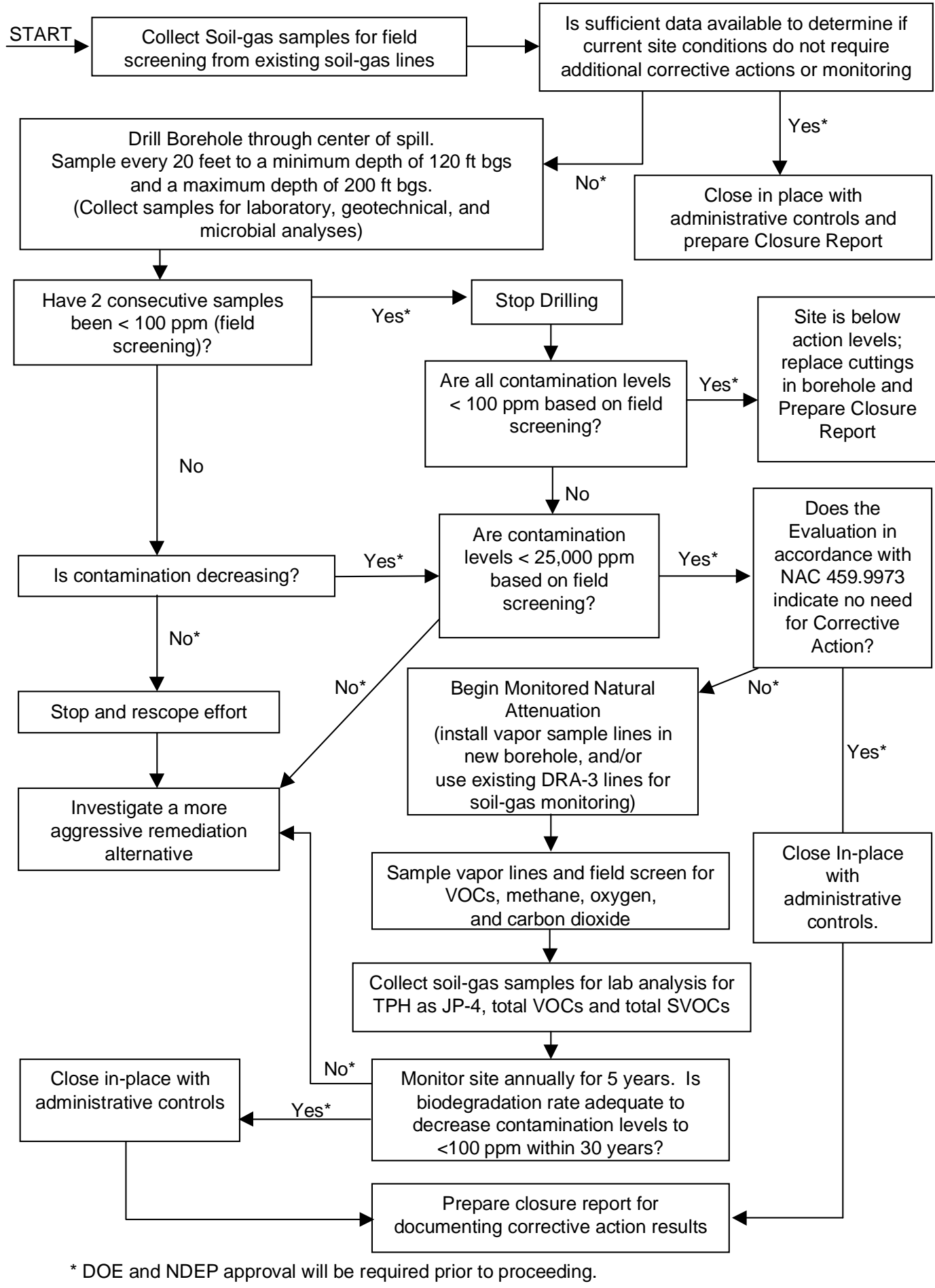

Figure 1-2

Corrective Action Unit 329 Decision Logic Diagram 
- Sample soil from near the center of the spill to a depth not exceeding 200 feet (ft) for total petroleum hydrocarbons (TPH) as JP-4, total VOCs, and total semivolatile organic compounds (SVOCs).

- Sample soils from near the center of the spill for geotechnical and microbial analyses.

- If administrative controls are necessary, use existing soil-gas sample points from DRA-3. If these points are unusable, install soil-gas sample points at appropriate depths below the ground surface as determined during the investigation and approved by the U.S. Department of Energy, Nevada Operations Office (DOE/NV) and Nevada Division of Environmental Protection (NDEP). If administrative controls are not necessary, the existing soil-gas sample points will be removed if required by DOE/NV or NDEP.

Section 2.0 of this SAFER Plan presents a description of CAU 329. 


\subsection{Unit Description and Closure Objectives}

This section presents the description of the CAS including its history, location, process knowledge, and closure standards.

\subsection{History}

Initially, the DRA was part of "Camp Desert Rock" in the 1950s and 1960s and used to support the early activities of the weapons testing program (REECo, 1991). When operational, the DRA consisted of the single runway (with access restricted to U.S. Department of Energy [DOE] and U.S. Department of Defense air traffic), several portable buildings, two underground tanks storing Jet-A fuel, and plumbing to several refueling areas on the ramp. The tank capacity of 22-DRA-3 was 25,000 gallons (gal). The 25,000-gal tank was the only one to have a recorded leak. The tank was bedded in sand and gravel and the base of the tank was $16 \mathrm{ft}$ below ground surface (bgs). The associated transfer pump was located below ground surface in a manhole directly above the tank.

The 25,000-gal tank was installed in 1980 and initially used for aviation gasoline and later for Jet-A, JP-4, and JP-5 fuel. The first spill from Tank 22-DRA-3 occurred between December 20 and 26, 1985, and was approximately 16,000 gal of Jet-A fuel (IT, 1998b). The second spill was discovered on August 14, 1987; however, the actual date the spill occurred is unknown. The second spill was estimated at 2,000 to 3,000 gal of JP-4 fuel. A third spill was reported on September 24, 1989, stating that an unknown amount and unknown fuel was possibly released.

Documentation supports that the spill in December 1985 resulted from a malfunctioning in-ground vertical turbine pump. It was determined that this malfunction occurred because the pump was left on over a holiday and the seals failed. It has been reported that the other spill also occurred from seal failure (IT, 1998b).

The piping system has not been used since December 22, 1990. On September 22, 1991, locks were placed on the valves to isolate the pipes from the tank. A Closure Notification form was submitted to NDEP stating the tank had been emptied and last used on February 19, 1993. At that time, the pumps and other lines associated with Tank 22-DRA-3 were secured. On January 27, 1994, Tank 22-DRA-3 was removed and samples were collected pursuant to NAC 459.9972. Although the samples 
indicated high levels of TPH, the tank cavity was backfilled because of safety and operational concerns. There has been no further action taken on this site since the tank removal.

\subsection{Site Location and Description}

The DRA is located about one-mile southwest of Mercury, Nevada, the main support area for the NTS (Figure 1-1). Corrective Action Unit 329, Area 22 Desert Rock Airstrip Fuel Spill (CAS 22-44-01) is located west of the control tower at the DRA in Area 22 of the NTS (Figure 2-1). The fuel spill resulted from a leak from the transfer pump after seal-failure. The spill was located approximately $675 \mathrm{ft}$ west of the control tower. The remaining pipelines for the tank are approximately $54 \mathrm{ft}$ north of the wooden shed and $10 \mathrm{ft}$ east of the metal shed housing the pump manhole (IT, 1998b). See Section 3.0 for a description of the work to be performed at this CAU.

\subsection{Process Knowledge}

Fuel storage tank 22-DRA-3 was used to store JP-4, JP-5, and Jet-A fuel for gas-turbine aircraft use. This tank has three reported spills from the transfer pump after seal-failure. In 1994, the tank was emptied and removed. Connecting piping was capped and locked and left at the surface.

The research study Application of In Situ Monitoring of Organics at a Jet-A Fuel Spill, performed by Dozier and Emer (REECo, 1991), was conducted from 1988 to 1990 at the Tank 22-DRA-3 fuel spill site. The purpose of the study was to investigate the use of instrumentation to detect the extent of impacted soil surrounding a fuel spill. The study determined the lateral and vertical extent of the fuel release at this site. The study stated that no free product was found during drilling and the soils were assumed to be at residual saturation. The study determined that the wetting front had advanced to a depth of $120 \mathrm{ft}$ bgs and that vapors exceeding 100 parts per million (ppm) had advanced to a depth of $160 \mathrm{ft}$ bgs. Any liquid movement now is thought to be controlled by capillary tension, diffusion, and vapor density transport. Total hydrocarbon concentration (THC) results at or above $100 \mathrm{ppm}$ were detected to a depth of $160 \mathrm{ft}$ and within $15 \mathrm{ft}$ horizontally from the point of release. The volume of contaminated soil at or above $100 \mathrm{ppm}$ is estimated to be approximately 4,200 cubic yards. High carbon dioxide levels detected during the study may indicate that the fuel is undergoing oxidation or biological degradation. The depth to groundwater is approximately $800 \mathrm{ft}$; therefore, the researchers concluded it to be unlikely that the groundwater supply has or will be affected by the spills. It is 


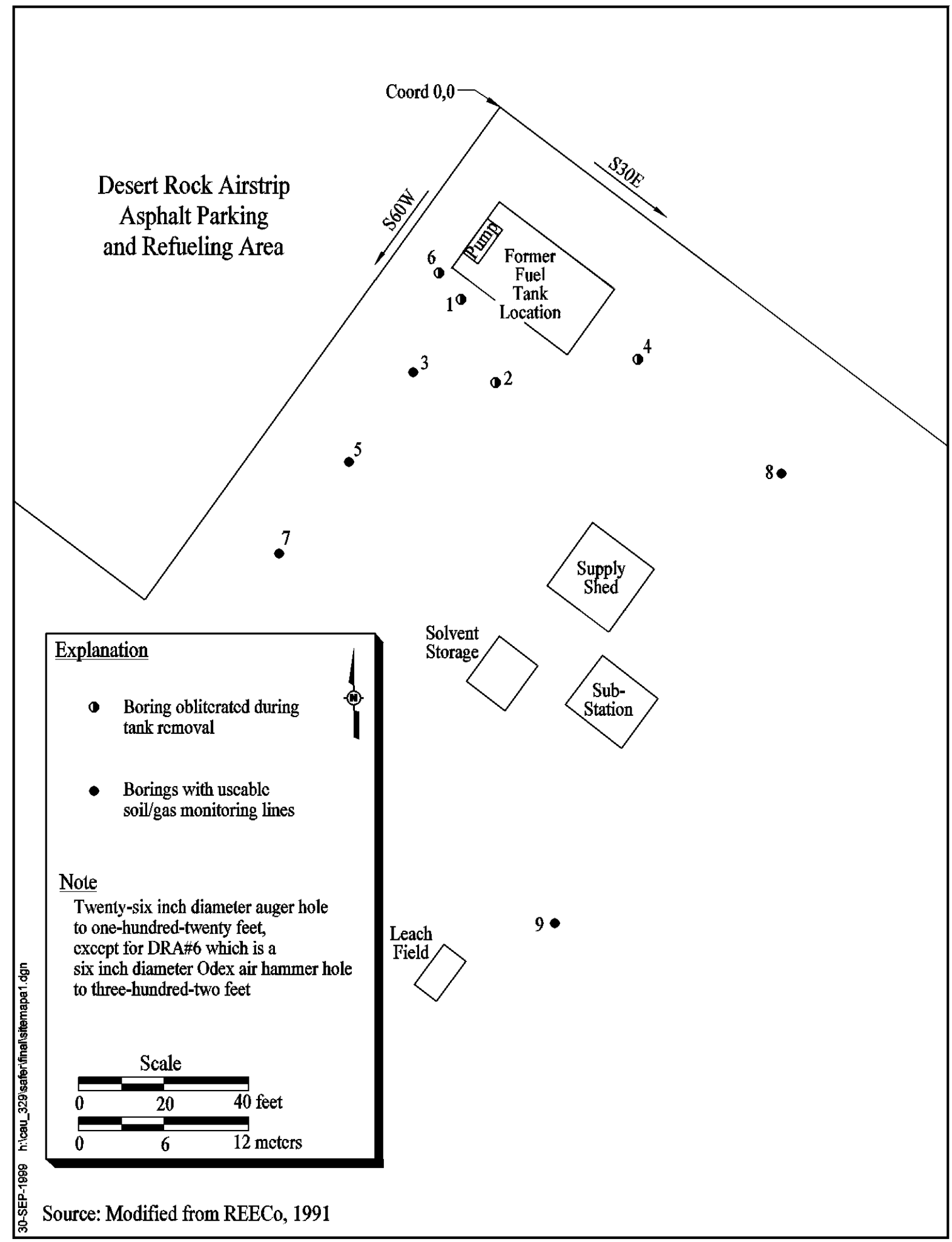

Figure 2-1 
important to note that this research was conducted independent of any site characterization or remediation actions required under regulatory compliance. In addition, the study reports THC values based on soil-gas samples which are not equivalent to the TPH values generated on soil analyzed by EPA method 8015 (modified).

In 1994, during tank removal, soil samples were collected from $1 \mathrm{ft}$ beneath the east and west ends of the tank. The results ranged from 1,780 milligrams/kilogram $(\mathrm{mg} / \mathrm{kg})$ to $1,970-\mathrm{mg} / \mathrm{kg}$ TPH as gasoline and less than $10-\mathrm{mg} / \mathrm{kg}$ TPH as diesel. Samples were taken from soil excavated and stockpiled from the east and west ends of the tank. Sample results from the east end had results that ranged from 1,930-mg/kg to 2,360-mg/kg TPH as gasoline. Sample results from the west end did not exceed the NAC 459.9973 action level of $100-\mathrm{mg} / \mathrm{kg}$ TPH. Metals detected in the samples did not reach action level limits. These samples were not analyzed for VOCs or SVOCs. Approximately 100 cubic yards of hydrocarbon-contaminated soil from the east-end soil pile was disposed in the Area 6 Hydrocarbon Landfill.

In February 1999, a field visit was made to determine the usability of the existing borings from the ISMO study. Borings DRA-1, DRA-2, DRA-4, and DRA-6 were not found and were probably obliterated during the tank removal (Figure 2-1). Borings DRA-3, DRA-5, DRA-7, DRA-8, and DRA-9 were located and gas-sampling lines were intact and tags showed the various depths, except DRA-3 had no tags to reveal the sampling line depths. No elevated photoionization detector readings were obtained and methane gas was not detected. Also, confirming the ISMO study, there was a decrease in oxygen and an increase in carbon dioxide towards the source area indicating probable natural attenuation at the site.

On March 16, 1999, a DQO meeting was conducted for this CAU and a preliminary DQO summary is provided in Appendix A. It is important to note that the DQO summary represents the status of the CAU on March 16, 1999; therefore, it reflects the actions proposed at that time.

\subsection{Closure Standards}

If the current site conditions exceed the NAC 459.9973 action level of $100-\mathrm{mg} / \mathrm{kg}$ TPH, the site conditions will be evaluated in accordance with NAC 459.9973 (1) (a-k) factors to determine if any 
corrective action will be required. Details of remediation and verification are discussed in Sections 3.2 and 3.3.

Corrective Action Unit 329 consists of hydrocarbon-contaminated soil; therefore, closure of this site will be accomplished by verifying that the residual soil contamination is undergoing natural attenuation and is not migrating. The closure activities will be completed using guidance from the following documents or permits:

- Comprehensive Environmental Response, Compensation, and Liability Act Preliminary Assessment of DOE's Nevada Operations Office Nuclear Weapons Testing Areas, Volume 1 (DRI, 1988).

- Industrial Sites Quality Assurance Project Plan, Nevada Test Site (DOE/NV, 1996).

- Nevada Environmental Restoration Project, Project Management Plan, Rev. 0 (DOE/NV, 1994).

- Nevada Test Site Underground Contaminants (REECo, 1986).

Field activities are presented in the following section. 


\subsection{Field Activities}

The rationale for the following field activities is to determine the concentration levels of contamination and to verify that the contamination area is undergoing natural attenuation at an adequate rate.

A Cultural Resource Survey is not required because all work will be completed in previously disturbed areas. Off-road driving in areas surrounding the site is not allowed. This site is located within the range of the desert tortoise; therefore, a desert tortoise survey will be conducted. During all site activities, the terms and conditions of the NTS Biological Opinion (USFWS, 1992) will be followed.

Before field activities begin, the following activities will be completed:

- Tortoise habitat and endangered species investigation

- Preparation of National Environmental Policy Act (NEPA) documentation

- Preparation of a Site-specific Health and Safety Plan (SSHASP)

A hazard assessment and SSHASP will be prepared for this project. The approved SSHASP will identify required personal protective equipment (PPE).

Field activities will include the following:

- Verify the serviceability and refurbishment, if required, of existing soil-gas sample points.

- Determine if the existing sample points can be used to determine corrective action.

- Drill a borehole to a minimum depth of $120 \mathrm{ft}$ bgs and a maximum depth of $200 \mathrm{ft}$ bgs.

- Collect and field-screen soil samples for laboratory analysis at 20-ft intervals within the borehole.

- Collect soil samples for geotechnical and microbial laboratory analysis. 
- Construct soil-gas sampling points within new borehole at depth if DRA-3 samples points are unusable.

- Collect and field screen soil-gas samples for laboratory analysis at 20-ft intervals within the borehole.

The decision logic for field activities is presented in Figure 1-2.

\subsection{Contaminants of Potential Concern}

The spills occurred from a pump connected to a tank that leaked aviation fuel (JP-4); therefore, the COPCs are petroleum hydrocarbons as JP-4, VOCs, and SVOCs for soils and soil-gas. Analytical methods and reporting limits to be used for this project are provided in Table 3-1. It is assumed that contamination migration has essentially ceased and is now undergoing biological degradation. It is anticipated that the analytical results of soil-gas and soil samples will support this assumption.

Table 3-1

CAU 329 Fuel Storage Area Contaminants of Potential Concern

\begin{tabular}{|c|c|c|c|c|c|c|c|}
\hline Analyte & Comments & $\begin{array}{c}\text { Field } \\
\text { Screening } \\
\text { Method }\end{array}$ & $\begin{array}{c}\text { Field } \\
\text { Screening } \\
\text { Level }\end{array}$ & $\begin{array}{c}\text { Conduct } \\
\text { Analytical? }\end{array}$ & $\begin{array}{c}\text { Analytical } \\
\text { Method }\end{array}$ & $\begin{array}{c}\text { Preliminary } \\
\text { Action } \\
\text { Level }\end{array}$ & Source $^{b}$ \\
\hline $\begin{array}{l}\text { Total } \\
\text { Petroleum } \\
\text { Hydrocarbons }\end{array}$ & $\begin{array}{l}\text { Potential for jet } \\
\text { fuel petroleum } \\
\text { hydrocarbons in } \\
\text { soil and soil-gas }\end{array}$ & Hanby & $>100$ ppm & Yes ${ }^{*}$ & 8015B modified ${ }^{\mathrm{a}}$ & $100 \mathrm{mg} / \mathrm{kg}$ & NAC $445 A$ \\
\hline Total VOCs & $\begin{array}{l}\text { Potential for jet } \\
\text { fuel petroleum } \\
\text { hydrocarbons in } \\
\text { soil and soil-gas }\end{array}$ & Headspace & $\begin{array}{l}20 \text { ppm or } 2.5 x \\
\text { background (use } \\
\text { greater value) }\end{array}$ & Yes & 8260B & $\mathrm{PRGs}^{\mathrm{c}}$ & \\
\hline Total SVOCs & $\begin{array}{l}\text { Potential for jet } \\
\text { fuel petroleum } \\
\text { hydrocarbons in } \\
\text { soil and soil-gas }\end{array}$ & $\mathrm{N} / \mathrm{A}$ & $\mathrm{N} / \mathrm{A}$ & Yes & $8270 \mathrm{C}$ & $\mathrm{PRGs}^{\mathrm{C}}$ & \\
\hline
\end{tabular}

${ }^{a}$ Test Methods for Evaluating Solid Waste, Third Edition, Parts 1-4, SW-846 (EPA, 1996)

${ }^{b} N D E P$ Corrective Action Regulations (NAC, 1998a)

'EPA Region IX Preliminary Remediation Goals (PRGs) (EPA, 1998)

${ }^{*}$ As specified in text Section A.5.0

\subsection{Remediation}

There are no anticipated active remediation activities associated with this project. If the current site conditions exceed the NAC 459.9973 action level of $100-\mathrm{mg} / \mathrm{kg}$ TPH, the site conditions will be 
evaluated in accordance with NAC 459.9973 (1) (a-k) factors to determine if any corrective action will be required.

The strategy for the CAU 329, Area 22 Desert Rock Airport Fuel Spill remediation includes verifying serviceability of existing soil gas sampling points and conducting a soil-gas survey prior to the drilling to determine current site conditions. The data will be evaluated to determine if adequate information is available to close in-place with administrative controls. All remediation activities will be coordinated with DOE/NV and the NDEP as shown on Figure 1-2 prior to beginning the next phase.

The remediation activities of the CAU 329, Area 22 Desert Rock Airport Fuel Spill will be as follows:

- Rotary sonic drilling will be used to drill a borehole within the former tank pit. Soil samples will be collected for field screening and laboratory analyses.

- The vertical extent of contamination will be determined; maximum depth is expected to be limited to $200 \mathrm{ft}$ bgs. The sample frequency will be at 20 - $\mathrm{ft}$ intervals. The bottom of the tank pit was approximately $16 \mathrm{ft}$ bgs. It is unknown to what depth the pit was excavated during the tank removal. It is assumed that the excavation depth was less than or equal to $20 \mathrm{ft}$. The first sample will be assumed to be from native material that was not disturbed during the tank removal activities. The ISMO study showed that the maximum depth of the wetting front was $120 \mathrm{ft}$ bgs and the maximum depth of vapors exceeding $100 \mathrm{ppm}$ was $160 \mathrm{ft}$ bgs. The drilling will continue to a minimum depth of $120 \mathrm{ft}$ bgs and a maximum depth of $200 \mathrm{ft}$ bgs.

- Field screen soil samples for the following:

- Volatile organic compounds using a photoionization detector at 20-ft intervals.

- Total petroleum hydrocarbons using the Hanby method to determine initial and peak concentrations, and to be used at depth on the last two samples collected with field-screening results below field-screening levels (FSLs) for VOCs. Additional depths may be screened using Hanby at the discretion of the Site Supervisor.

- At each sample depth where COPCs are above the FSLs, the following will apply:

- Continue field screening to the next depth. If field-screening results are less than FSLs at a target depth, continue drilling an additional $20 \mathrm{ft}$; resample and field screen until two consecutive samples are below FSLs or until a maximum depth of $200 \mathrm{ft}$. If the depth is 
less than $120 \mathrm{ft}$, continue to drill regardless of field-screening results. If field-screening results at $100 \mathrm{ft}$ and $120 \mathrm{ft}$ are both less than FSLs, stop drilling.

- Submit a minimum of two samples for laboratory analysis: the sample with the highest field-screening result and the first of two samples with results less than FSLs.

- If COPCs are below the field-screening results for all samples for this site, a minimum of two samples will be submitted for laboratory analyses. The samples will be selected based on FSLs, visual indicators, or as determined by the Site Supervisor. One of the selected samples will be from the maximum depth.

- Additional samples may be collected and submitted for analyses at the discretion of the Site Supervisor.

- Perform laboratory analyses for TPH as JP-4, total VOCS, and total SVOCs.

- If COPCs are not detected, prepare and submit a Closure Report (CR).

The following decision rules shown in Table 3-2 are applicable to the CAU 329, Area 22 Desert Rock Airport Fuel Spill and will be used to guide the existing data evaluation and any subsequent investigation.

- If either of the following occur in the course of the investigation, the investigation will be halted and rescoped as necessary:

- The conceptual model fails to such a degree that rescoping is required.

- Sufficient data are collected to support evaluation of corrective actions.

- If analytical results are not adequate for preparation of a CR and/or waste management purposes, additional sampling may be conducted and submitted for analyses at the discretion of the Site Supervisor.

- If COPCs extend beyond $200 \mathrm{ft}$, the investigation will be rescoped.

- If laboratory results indicate the presence of COPCs above preliminary action levels (PALs), an evaluation in accordance with NAC 459.9973(1) (NAC, 1998b) will be performed to determine additional requirements.

- If COPCs are not identified above PALs, a CR will be prepared according to the outline agreed upon by the NDEP and DOE/NV. 
Table 3-2

CAU 329 Investigation-Specific Decision Points and Rules

\begin{tabular}{|c|c|c|c|}
\hline $\begin{array}{l}\text { Investigation } \\
\text { Activity }\end{array}$ & Decision Point & Decision Result & Decision Rule \\
\hline \multirow{4}{*}{ Soil Sample Collection } & \multirow{2}{*}{$\begin{array}{l}\text { Are headspace results above } \\
\text { field-screening levels? }\end{array}$} & Yes & $\begin{array}{l}\text { Verify results with Hanby. Continue investigation if less than } \\
\text { maximum target depth. }\end{array}$ \\
\hline & & No & $\begin{array}{l}\text { Verify results with Hanby. Continue investigation if less than } \\
\text { minimum target depth. Collect a minimum of two samples for } \\
\text { laboratory analysis based on Site Supervisor guidance. }\end{array}$ \\
\hline & \multirow{2}{*}{$\begin{array}{l}\text { Are Hanby results above field- } \\
\text { screening levels? }\end{array}$} & Yes & $\begin{array}{l}\text { Collect sample for laboratory analysis from area with highest } \\
\text { field-screening results. }\end{array}$ \\
\hline & & No & $\begin{array}{l}\text { Collect a minimum of two samples for laboratory analysis based } \\
\text { on Site Supervisor guidance. }\end{array}$ \\
\hline
\end{tabular}




\subsection{Verification}

Soil samples will be collected for analyses to verify field-screening results and that the site is undergoing natural attenuation and contamination is not migrating. A minimum of one boring will be drilled in the center of the contamination area and soil (based on field-screening results) samples will be submitted for laboratory analysis of COPCs discussed in Section 3.2. The results of the investigation will be compared to previously collected data to determine if the plume has stabilized, increased, or decreased in size.

If the current site conditions exceed the NAC 459.9973 action level of $100-\mathrm{mg} / \mathrm{kg}$ TPH, the site conditions will be evaluated in accordance with NAC 459.9973 (1) (a-k) factors to determine if any corrective action will be required. If the evaluation determines that the site cannot be administratively closed, additional activities will be taken to monitor the natural attenuation at the site.

The soil-gas will be sampled to monitor natural attenuation in the contaminated area using existing soil-gas sample points and/or additional soil-gas sample points installed at appropriate depths below the ground surface as determined during the investigation and approved by DOE/NV and the NDEP. The soil-gas will be field screened for VOCs, $\mathrm{O}_{2}, \mathrm{CO}_{2}$, and methane. Samples exceeding FSLs will be submitted for laboratory analysis of TPH as JP-4, VOCs, and SVOCs. Sampling will occur on an annual basis to monitor constituent concentrations (EPA, 1995). The monitoring will continue for five years to determine the natural attenuation rate of the plume.

A comparison of analytical results for soil and soil-gas samples will be made during the installation of the monitoring points within the borehole. Additional evaluation of analytical results from different depths within the borehole will be made to determine current vertical conditions. The levels to be used for verification of natural attenuation are often site-specific. Final criteria to be used for verification will be determined as analytical results are evaluated. The criteria will be submitted for approval by DOE/NV and the NDEP before implementation. 
Verification of natural attenuation will be demonstrated by a combination of some or all of the following factors:

- Carbon dioxide level - Carbon dioxide is a by-product of natural attenuation. An increase or decrease in the carbon dioxide level will indicate an increase or decrease in microbial activity. This will be determined from field-screening results.

- Oxygen level - Oxygen is a growth stimulant for aerobic microbes. An increase or decrease in the oxygen level will indicate an increase or decrease in microbial activity. This will be determined from field-screening results.

- Mass balance of contaminants - A decrease in the total mass of contaminants over time provides a direct indication of natural attenuation. This will be determined from field screening and laboratory results.

- Ratio of contaminants - An increase in the ratio of recalcitrant contaminants to easily degradable contaminants indicates natural attenuation. This will be determined from laboratory results.

- Metabolic intermediaries - The formation of metabolic intermediaries, incompletely degraded contaminants of concern (COCs), indicates natural attenuation. This will be determined from laboratory results.

\subsection{Closure}

If the current site conditions exceed the NAC 459.9973 action level of $100-\mathrm{mg} / \mathrm{kg}$ TPH, the site conditions will be evaluated in accordance with NAC 459.9973 to determine if any corrective action will be required. If the evaluation does not determine that the site can be administratively closed, additional activities will be performed to monitor the natural attenuation at the site (see Section 3.3). Data from monitoring activities will be evaluated to determine if the natural attenuation rate at the site will be adequate to degrade remaining COCs to less than $100 \mathrm{mg} / \mathrm{kg}$ in 30 years. The natural attenuation rate will be verified as discussed in Section 3.3.

The activities required to achieve closure are as follows:

- Field screening of soil-gas samples from existing soil-gas lines, if accessible.

- Complete one borehole near the center of contamination and collect soil samples for field screening and laboratory analyses. 
- Collect samples for laboratory microbial and geotechnical analyses.

- $\quad$ Prepare a SAFER CR with approval from NDEP documenting the completed activities.

\subsection{Duration}

The closure activities are anticipated to begin several weeks after approval of this plan by the NDEP, probably in early fiscal year 2000. Closure activities are outlined as follows:

- $\quad$ Prepare SSHASP documentation and submit profile for review and approval.

- Prepare NEPA checklist for activities.

- Prepare Field Management Plan for this SAFER Work Plan.

- Submit Final SAFER Work Plan to the NDEP; FFACO milestone deadline of December 31, 1999.

- Begin closure activities; work is anticipated to last one week and begin in early fiscal year 2000.

- $\quad$ Submit Final SAFER CR to the NDEP; FFACO milestone deadline of August 31, 2000.

If corrective actions will be required, the site will be monitored as discussed in Sections 3.3 and 3.4.

The schedule will require modification if conditions exist outside of the assumptions on which the schedule was developed. Flexibility has been placed in the project schedule to account for minor difficulties (e.g., weather, equipment breakdowns, and personnel availability). Appendix B provides the organizational structure for this project. The DOE/NV will keep the NDEP apprised of any condition that may impact the project schedule. 


\subsection{Reports and Records Availability}

Once field activities have started, a daily report will be prepared. The report summarizes the daily project accomplishments and any problems that may have been encountered. The report will be provided to the DOE/NV Task Manager for submittal to the NDEP.

On completion of the field activities, a closure report will be prepared to include the following:

- Introduction (Purpose and Scope)

- Closure Activities (Description of Field Activities)

- Waste Disposition

- Conclusions

The final report will be submitted to the NDEP for review and approval. This document will be available in the DOE/NV public reading rooms located in Las Vegas and Carson City, Nevada, or by contacting the DOE/NV Project Manager. The NDEP maintains the official Administrative Record for all activities conducted under the auspices of the FFACO. 


\subsection{Investigation/Remediation Waste Management}

Management of investigation-derived waste (IDW) will be based on regulatory requirements, field observations, process knowledge, and the results of laboratory analysis of CAU 329 investigation samples. Decontamination activities will be performed according to approved contractor procedures specified in the contractor field instructions and as appropriate for the COPCs likely to be identified at the CAU.

Waste other than soil or waste associated with the Hanby method, is considered potentially contaminated waste only by virtue of contact with potentially contaminated media. Therefore, sampling and analysis of IDW, separate from analyses of site characterization samples, will generally not be required. Rinsate may be analyzed separately to determine final disposition. The data generated as a result of site characterization and process knowledge will be used to assign the appropriate waste type (i.e., sanitary, TPH, or hazardous).

There is no process knowledge that indicates specific hazardous waste constituents were disposed of at this CAU. Therefore, if contaminants are identified, they will be considered characteristic rather than listed hazardous wastes. Sanitary, TPH, or hazardous waste, if generated, will be managed and disposed of in accordance with DOE Orders, U.S. Department of Transportation (DOT) regulations, Resource Conservation and Recovery Act (RCRA) regulations, Nevada Revised Statutes, Nevada Administrative Code, and agreements and permits between DOE/NV and NDEP.

In the following sections, operational requirements are provided for managing, sanitary, TPH, and hazardous waste. However, upon initial generation, the waste will be managed according to RCRA requirements until laboratory analyses are received and a final waste determination is made.

\subsection{Waste Minimization}

Investigation activities have been planned to minimize IDW generation. Decontamination activities are planned to minimize the use of rinsate, and will be conducted in accordance with approved contractor procedures. Disposal sampling equipment, decontamination rinsate, and PPE will be segregated to the greatest extent possible to minimize the generation of hazardous waste. 


\subsection{Potential Waste Streams}

Waste generated during the investigation activities will include the following:

- Soil cuttings from boreholes

- Spent field test kits

- Rinsate

- Used PPE

- Plastic

\subsection{Investigation-Derived Waste Management}

Management requirements for sanitary, hydrocarbon, and hazardous waste are discussed further in the following sections. The IDW generated in the exclusion zone will be managed as hazardous waste until laboratory results indicate the absence of RCRA-regulated constituents.

\subsubsection{Sanitary Waste}

Sanitary waste will be contained in plastic bags and will be transported to an approved solid waste management unit.

\subsubsection{Hydrocarbon Waste}

The action level for soil contaminated with hydrocarbons is $100 \mathrm{mg} / \mathrm{kg}$ in the state of Nevada (NAC, 1998a). Soils and associated IDW with TPH levels above $100 \mathrm{mg} / \mathrm{kg}$ shall be disposed of in accordance with all applicable regulations in a hydrocarbon landfill.

\subsubsection{Hazardous Waste}

Suspected hazardous waste will be managed in accordance with RCRA and State of Nevada hazardous waste management regulations, interpreted as follows. Suspected hazardous waste will be placed in 55-gal drums that meet DOT specifications (49 CFR 172) (CFR, 1998j) and will be locked or fitted with tamper-indicating devices. Drums shall be compatible with the waste in accordance with the requirements of 40 CFR 265.172 (CFR, 1998a). No incompatible wastes are expected to be generated; however, if incompatible waste is encountered in the field, it will be managed in accordance with 40 CFR 265.177 (CFR, 1998b) (i.e., shall not be placed in the same container) and shall be separated so that in the event of a spill, leak, or release, incompatible waste shall not contact 
one another. Containers shall be handled and inspected in accordance with the requirements of 40 CFR 265.173 and 174, respectively (CFR, 1998c and d).

Hazardous waste shall be characterized in accordance with the requirements of 40 CFR 261 (CFR, 1998e). Characterization will be based on laboratory results and process knowledge. Containers of IDW pending characterization will be marked with the words "Hazardous Waste Pending Analysis" until its regulatory status can be determined through interpretation and evaluation of laboratory results. Traceability shall be maintained by assigning a unique waste tracking number to each container and by maintain records that trace the IDW back to the associated samples. After receipt of analytical results, hazardous waste, if identified, will be labeled and marked in accordance with the requirements of 40 CFR 262.32 (CFR, 1998f).

Hazardous waste management methods that include the establishment of Satellite Accumulation Areas or a 90-day Hazardous Waste Accumulation Area will be employed to temporarily accumulate IDW pending characterization. These methods will be appropriate for the amount of waste being accumulated and in compliance with applicable State of Nevada and federal requirements.

Suspected hazardous waste will be accumulated as applicable at or near the site of generation for up to 90 days in accordance with 40 CFR 262.34 (CFR, 1998g). Prior to or on the ninetieth day of accumulation as specified in 40 CFR 262.34(a) (CFR, 1998g), hazardous waste will be shipped by a licensed/permitted hazardous waste transporter to a permitted treatment, storage, and disposal facility. A copy of the uniform hazardous waste manifest shall be provided to the NDEP after the hazardous waste shipment is completed. If hazardous waste must remain on-site for longer than 90 days due to unforeseen, temporary, and uncontrollable circumstances, a letter requesting an extension for up to 30 days, will be sent to the NDEP in accordance with 40 CFR Part 262.11(b) (CFR 1998h). 


\subsection{References}

CFR, see Code of Federal Regulations.

Code of Federal Regulations. 1998a. 40 CFR 265.172, "Compatibility of Waste with Container."

Washington, DC: U.S. Government Printing Office.

Code of Federal Regulations. 1998b. 40 CFR 265.177, "Special Requirements for Incompatible Wastes." Washington, DC: U.S. Government Printing Office.

Code of Federal Regulations. 1998c. 40 CFR 265.173, "Management of Containers."

Washington, DC: U.S. Government Printing Office.

Code of Federal Regulations. 1998d. 40 CFR 265.174, “Inspections.” Washington, DC:

U.S. Government Printing Office.

Code of Federal Regulations. 1998e. 40 CFR 261, "Identification and Listing Of Hazardous Waste."

Washington, DC: U.S. Government Printing Office.

Code of Federal Regulations. 1998f. 40 CFR 262.32, "Marking." Washington, DC:

U.S. Government Printing Office.

Code of Federal Regulations. 1998g 40 CFR 262.34, “Accumulation Time." Washington, DC:

U.S. Government Printing Office.

Code of Federal Regulations. 1998h. 40 CFR Part 262.11, "Hazardous Waste Determination."

Washington, DC: U.S. Government Printing Office.

Code of Federal Regulations. 1998i. 40 CFR Part 280, “Technical Standards and Corrective Action

Requirements for Owner and Operators of Underground Storage Tanks." Washington, DC:

U.S. Government Printing Office.

Code of Federal Regulations. 1998j. 49 CFR 172, "Hazardous Materials Table, Special Provisions, Hazardous Materials Communications, Emergency Response Information, and Training."

Washington, DC: U.S. Government Printing Office.

DOE/NV, see U.S. Department of Energy, Nevada Operations Office.

Desert Research Institute. 1988. Comprehensive Environmental Response, Compensation, and Liability Act Preliminary Assessment of DOE's Nevada Operations Office Nuclear Weapons Testing Areas, Vol. 1, April 1988. Las Vegas, NV.

DRI, see Desert Research Institute. 
FFACO, see Federal Facility Agreement and Consent Order.

Federal Facility Agreement and Consent Order. 1996, as amended. Agreed to by the State of Nevada, the U.S. Department of Energy, and the U.S. Department of Defense.

IT, see IT Corporation.

IT Corporation. 1998a. Nevada Test Site Road and Facilities Road, and Facility Map modified from Raytheon Services Nevada Road and Facility Map, 1992 and Bechtel Nevada, 1997.

Las Vegas, NV.

IT Corporation. 1998b. Project Files for CAU 329, CAS 22-44-01. Includes field activity daily logs, field forms, Geographic Positioning System coordinates, photodocumentation forms, and checkprints. Also included is a Spill Notification Report prepared by BN. Las Vegas, NV.

NAC, see Nevada Administrative Code.

Nevada Administrative Code. 1998a. NAC445A.226 - 445A.22755, "Action Levels for Contaminated Sites.” Carson City, NV: Nevada Division of Environmental Protection.

Nevada Administrative Code. 1998b. NAC459.9921 - 459.999, "Storage Tanks.” Carson City, NV: Nevada Division of Environmental Protection.

REECo, see Reynolds Electrical \& Engineering Co., Inc.

Reynolds Electrical \& Engineering Co., Inc. 1986. Nevada Test Site Underground Contaminants. Las Vegas, NV.

Reynolds Electrical \& Engineering Co., Inc. 1991. The Nevada Test Site Application of In Situ Monitoring of Organics at a Jet-A Fuel Spill, DOE/NV/10630--12, January. Prepared by Brian Dozier and Dudley Emer. Las Vegas, NV.

USFWS, see U.S. Fish and Wildlife Services.

U.S. Department of Energy, Nevada Operations Office. 1994. Project Management Plan, Rev. 0. Las Vegas, NV.

U.S. Department of Energy, Nevada Operations Office. 1996. Industrial Sites Quality Assurance Project Plan, Nevada Test Site, Nevada, Rev. 1, DOE/NV--372. Las Vegas, NV. 
U.S. Environmental Protection Agency. 1995. How to Evaluate Alternative Cleanup Technologies for Underground Storage Tank Sites: A Guide for Corrective Action Plan Reviewers, EPA510-B-95-007. Washington, DC: Solid Waste and Emergency Response.

U.S. Environmental Protection Agency. 1996. Test Methods for Evaluating Solid Waste, Physical/Chemical Methods, SW-846, Third Edition, CD ROM, PB97-501928GEI. Washington, DC.

U.S. Environmental Protection Agency. 1998. Memo from S.J. Smucker regarding Region 9 Preliminary Remediation Goals (PRGs), 1 August. San Francisco, CA.

U.S. Fish and Wildlife Services. 1992. Nevada Test Site, Nevada Biological Opinion, Terms and Conditions. 


\section{Appendix A}

\section{Data Quality Objectives}

Note: The DQO summary represents the status of the CAU on March 16, 1999;

therefore, it reflects the proposed characterization activities at that time. 


\section{A.1.0 Introduction}

\section{A.1.1 Problem Statement}

Hydrocarbons have been released at the CAU 329, Area 22 Desert Rock Airstrip Fuel Spill

(CAS 22-44-01). Existing information about the nature and extent of potential contamination may be sufficient to evaluate and select preferred corrective actions for this site. The extent and contamination concentrations were previously determined and documented during the Application of In Situ Monitoring of Organics at a Jet-A Fuel Spill (REECo, 1991) and tank removal.

It is believed that the existing information is adequate to select a preferred alternative to close the site under State of Nevada regulations and DOE requirements. If it is determined that the existing information is not adequate to close the site under State of Nevada regulations and DOE requirements, an investigation will be conducted. The CAU 329, Area 22 Desert Rock Airport Fuel Spill investigation will be based on the DQOs developed by representatives of NDEP and DOE/NV. This investigation will determine current concentrations of COPCs within the Desert Rock Airport Fuel Spill.

Sections A.1.0 through A.4.0 are background information and site description to be used to support the selection of a preferred alternative or additional investigation strategy. Sections A.5.0 through A.7.0 support additional investigation activities if required.

A DQO kickoff meeting was held on March 16, 1999. Table A.1-1 identifies the participants in this meeting. 
Table A.1-1

DQO Kickoff Meeting Participants

\begin{tabular}{|c|c|c||}
\hline \multirow{2}{*}{ Participant } & \multirow{2}{*}{ Affiliation } & Meeting Date \\
\cline { 3 - 3 } & & $\begin{array}{c}\text { Kickoff Meeting } \\
\text { March 16, 1999 }\end{array}$ \\
\hline \hline David Friedman & NDEP & $\mathrm{X}$ \\
\hline Clayton Barrow & DOE/NV & $\mathrm{X}$ \\
\hline Robert Curiale & IT & $\mathrm{X}$ \\
\hline Lydia Coleman & SAIC & $\mathrm{X}$ \\
\hline Mark DiStefano & IT & $\mathrm{X}$ \\
\hline Syl Hersh & IT & $\mathrm{X}$ \\
\hline Dudley Emer & BN & $\mathrm{X}$ \\
\hline Jerry Bonn & BN & $\mathrm{X}$ \\
\hline Dawn Arnold & SAIC & $\mathrm{X}$ \\
\hline Jeffrey Johnson & IT & $\mathrm{X}$ \\
\hline John Stokowski & IT & $\mathrm{X}$ \\
\hline Robert Eastmond & IT & $\mathrm{X}$ \\
\hline Mary Todd & SAIC & $\mathrm{X}$ \\
\hline Jeanne Wightman & MACTEC & $\mathrm{X}$ \\
\hline
\end{tabular}

BN - Bechtel Nevada

DOE/NV - U.S. Department of Energy, Nevada Operations Office

IT - IT Corporation

MACTEC - Management Analysis Company Technologies

NDEP - Nevada Division of Environmental Protection

SAIC - Science Applications International Corporation 


\section{A.2.0 Conceptual Model}

The CAU 329, Area 22 Desert Rock Airstrip Fuel Spill, is the location of the former UST 22-DRA-3. The UST was used to store petroleum to refuel aircraft using the Camp Desert Rock Airstrip in Area 22 of the NTS, Nevada. The CAU 329 site is shown on basic information maps for the Desert Rock Airstrip (Holmes \& Narver, 1986). The Desert Rock Airstrip was used by the national laboratories to transport personnel and material to and from NTS. The former UST was a steel tank with a lined interior. Fuels reportedly stored in the UST were aviation gasoline, Jet-A, Jet-A50, JP-4, and JP-5.

A spill of approximately 16,000 gals of Jet-A fuel occurred between December 20 and 26, 1985. The spill was identified on January 14, 1986. A second spill of approximately 2,000 to 3,000 gals of JP-4 fuel was discovered on August 14, 1987. Both spills were caused by the pump being left on for an extended period of time resulting in the failure of pump seals and a leakage of fuel.

The conceptual model for the CAU 329, Area 22 Desert Rock Airstrip Fuel Spill, is provided in Table A.2-1. 
Table A.2-1

Conceptual Model Element Descriptions

(Page 1 of 2)

\begin{tabular}{|c|c|c|}
\hline $\begin{array}{l}\text { Conceptual Model } \\
\text { Element }\end{array}$ & Description & Source \\
\hline \multirow{3}{*}{$\begin{array}{c}\text { Fuel Spill } \\
(\text { CAS 22-44-01) }\end{array}$} & $\begin{array}{l}\text { The CAU } 329 \text {, Area } 22 \text { Desert Rock Airstrip Fuel Spill, is located in } \\
\text { Area } 22 \text { of the NTS. }\end{array}$ & $\begin{array}{l}\text { Engineering drawings (Holmes } \\
\text { \& Narver, 1986), } \\
\text { FADL (IT, 1998), } \\
\text { Aerial photographs } \\
\text { (EG\&G/EM, 1991) }\end{array}$ \\
\hline & $\begin{array}{l}\text { Former UST 22-DRA-3 was located approximately } 206 \text { meters west } \\
\text { of the control tower. }\end{array}$ & $\begin{array}{l}\text { FADL (IT, 1998) Aerial } \\
\text { photographs } \\
\text { (EG\&G/EM, 1991), Engineering } \\
\text { drawings } \\
\text { (Holmes \& Narver, 1986) }\end{array}$ \\
\hline & $\begin{array}{l}\text { The piping was last used in December 1990. The UST was pumped } \\
\text { out in February } 1993 \text { and removed in January } 1994 .\end{array}$ & $\begin{array}{l}\text { Temporary UST Closure } \\
\text { (DOE/NV, 1992) UST Closure } \\
\text { Notification (DOE/NV, 1994) }\end{array}$ \\
\hline \multirow{4}{*}{ Evidence for COPCs } & $\begin{array}{l}\text { The site was used for the storage of fuel for aircraft. Types of fuel } \\
\text { reportedly stored in the UST were aviation gas, JP-4, JP-5, Jet-A, } \\
\text { and Jet-A50. }\end{array}$ & $\begin{array}{l}\text { Process knowledge } \\
\text { (DOE/NV, 1996) (DOE, 1988) } \\
\text { UST Closure Notification } \\
\text { (DOE/NV, 1994) Engineering } \\
\text { drawings } \\
\text { (Holmes \& Narver, 1986) }\end{array}$ \\
\hline & $\begin{array}{l}\text { A reported spill of approximately } 16,000 \text { gal of Jet-A occurred } \\
\text { between December } 20-26,1985 \text {. A second reported spill of } \\
\text { approximately } 3,000 \text { gal of JP-4 was discovered on August } 14,1987 \text {. }\end{array}$ & Spill Report (IT, 1998) \\
\hline & $\begin{array}{l}\text { The study Application of In-Situ Monitoring of Organics at a Jet-A fuel } \\
\text { Spill (REECo, 1991) determined the vertical extent of contamination } \\
\text { based on vapors. The lateral extent was partially determined based } \\
\text { on vapors. }\end{array}$ & ISMO (REECo, 1991) \\
\hline & $\begin{array}{l}\text { Samples collected under the UST during removal on } \\
\text { January } 27,1994 \text {, had results exceeding the } 100-\mathrm{mg} / \mathrm{kg} \text { action level. }\end{array}$ & Work Request (REECo, 1994) \\
\hline
\end{tabular}


Table A.2-1

Conceptual Model Element Descriptions

(Page 2 of 2)

\begin{tabular}{|c|c|c|}
\hline $\begin{array}{c}\text { Conceptual Model } \\
\text { Element }\end{array}$ & Description & Source \\
\hline \multirow{5}{*}{ Extent of COPCs } & $\begin{array}{l}\text { COPCs released at the site are assumed to be at lower } \\
\text { contaminant concentrations due to biodegradation of } \\
\text { petroleum products. }\end{array}$ & $\begin{array}{l}\text { Degradation due to natural } \\
\text { biological processes }\end{array}$ \\
\hline & $\begin{array}{l}\text { The extent of lateral contamination is expected to be } \\
\text { centered around the former tank pit area. The lateral extent } \\
\text { is expected to be limited beyond the former tank pit area of } \\
\text { the site. The reported releases at the site are most likely due } \\
\text { to failure of pump seals and resulted in fuel impacting the } \\
\text { higher permeable tank pit and soils beneath it. }\end{array}$ & ISMO (REECo, 1991) \\
\hline & $\begin{array}{l}\text { Vertical extent of contamination wetting front to } 120 \mathrm{ft} \text { bgs } \\
\text { based on Jet-A signature and neutron probe counts, vapors } \\
\text { exceeding action levels to } 160 \mathrm{ft} \text {. }\end{array}$ & ISMO (REECo, 1991) \\
\hline & $\begin{array}{l}\text { The site was used for hydrocarbon storage from } 1980 \text { to } \\
\text { 1994. Annual precipitation is not adequate to cause } \\
\text { appreciable downward contaminant movement. }\end{array}$ & $\begin{array}{l}\text { ISMO (REECo, 1991) } \\
\text { Process knowledge } \\
\text { (DOE/NV, 1996) }\end{array}$ \\
\hline & $\begin{array}{l}\text { The surface area in the vicinity of the former UST is the } \\
\text { paved parking and refueling area or compacted from high } \\
\text { traffic volume limiting infiltration of surface water. }\end{array}$ & ISMO (REECo, 1991) \\
\hline Future Use of the Site & $\begin{array}{l}\text { Solar enterprise zone per the NTS Environmental Impact } \\
\text { Statement. The land area is designated for the development } \\
\text { of a solar energy power-generation facility, and light industrial } \\
\text { equipment and commercial manufacturing capability. }\end{array}$ & $\begin{array}{l}\text { Environmental Impact } \\
\text { Statement } \\
\text { (DOE/NV, 1996) }\end{array}$ \\
\hline Potential Receptors & Site workers & NTS excavation activities \\
\hline Exposure Pathways & $\begin{array}{l}\text { Ingestion, inhalation, and dermal contact; groundwater is not } \\
\text { considered an exposure pathway; depth to groundwater is } \\
\text { approximately } 800 \mathrm{ft} \text { and groundwater impacts are not } \\
\text { anticipated. There is no surface water in the area. }\end{array}$ & \\
\hline
\end{tabular}




\section{A.3.0 Potential Contaminants}

Hydrocarbons associated with UST 22-DRA-3 at the Desert Rock Airstrip may include JP-4 and Jet-A. Reported releases at the CAU indicate that approximately 16,000 gals of Jet-A fuel was released in December 1985. A second reported release of approximately 3,000 gals of JP-4 occurred in August 1987. Residual amounts of these fuels are expected to be found on site.

JP-4 is a broad cut, naptha jet fuel, similar to kerosene. The composition of JP-4 is approximately 65 percent gasoline and 35 percent light petroleum distillates. Actual fuel constituents will be determined by precursor crude oils and refining processes. Both JP-4 and Jet-A are kerosene-based, turbine fuels for aircraft. Jet-A is a commercial fuel and JP-4 is a military fuel (Coordinating Research Council, Inc., 1988).

COPCs for this site are TPH as gasoline and diesel-range organics (Table A.3-1). 
Table A.3-1

CAU 329 Fuel Storage Area

Contaminants of Potential Concern

\begin{tabular}{||l|l|l|l|l|l|l|l|}
\hline Analyte & Comments & $\begin{array}{c}\text { Field- } \\
\text { Screening } \\
\text { Method }\end{array}$ & $\begin{array}{c}\text { Field- } \\
\text { Screening } \\
\text { Level }\end{array}$ & $\begin{array}{c}\text { Conduct } \\
\text { Analytical? }\end{array}$ & $\begin{array}{c}\text { Analytical } \\
\text { Method }\end{array}$ & $\begin{array}{c}\text { Preliminary } \\
\text { Action } \\
\text { Level }\end{array}$ & $\begin{array}{c}\text { Source } \\
\text { bevel }\end{array}$ \\
\hline \hline $\begin{array}{l}\text { Total } \\
\text { Petroleum } \\
\text { Hydrocarbons }\end{array}$ & $\begin{array}{l}\text { Potential for jet } \\
\text { fuel petroleum } \\
\text { hydrocarbons }\end{array}$ & Hanby & $>100 \mathrm{ppm}$ & Yes $^{*}$ & $8015 \mathrm{~B}$ modified $^{\mathrm{a}}$ & $100 \mathrm{mg} / \mathrm{kg}$ & $\mathrm{NAC} 445 \mathrm{~A}$ \\
\hline
\end{tabular}

${ }^{a}$ Test Methods for Evaluating Solid Waste, Third Edition, Parts 1-4, SW-846 (EPA, 1996)

${ }^{b}$ NDEP Corrective Action Regulations (NAC, 1998)

${ }^{*}$ As specified in text Section A.5.0 


\section{A.4.0 Decisions and Inputs}

\section{A.4.1 Decisions}

Determine if the existing data are sufficient to evaluate corrective actions.

If additional information is required the decisions to be resolved by the investigation are as follows:

- Determine current COPC concentrations in the vicinity of the former tank pit.

- If COPCs are present, determine whether COPC concentrations exceed FSLs.

- If COPCs are present, determine whether COPC concentrations exceed PALs.

- Determine the current extent of contamination (or absence of contamination) with enough certainty to develop and evaluate a range of potential corrective actions, including closure in place and clean closure.

\section{A.4.2 Inputs and Strategy}

Inputs are those elements of information used to support the decisions in addressing the identified problem. A list of information inputs, existing data, identified data gaps, and brief strategies are discussed in Table A.4-1. A more detailed discussion of investigation strategies is found in Section A.5.0. 
Table A.4-1

Decisions, Inputs, and General Strategies

(Page 1 of 2)

\begin{tabular}{|c|c|c|c|c|}
\hline Decision & Input & Existing Data & Data Gap & Strategy \\
\hline $\begin{array}{l}\text { Is available information } \\
\text { adequate to evaluate } \\
\text { corrective actions for the } \\
\text { site? }\end{array}$ & Corrective action alternatives & $\begin{array}{l}\text { ISMO study and tank pull } \\
\text { analytical results }\end{array}$ & $\begin{array}{l}\text { Current contamination } \\
\text { concentrations }\end{array}$ & $\begin{array}{l}\text { Evaluate corrective action alternatives } \\
\text { based on previously collected data to } \\
\text { determine preferred alternative. }\end{array}$ \\
\hline \multirow[b]{2}{*}{$\begin{array}{l}\text { Are COPCs present above } \\
\text { PALs at site? }\end{array}$} & $\begin{array}{l}\text { Current contaminant } \\
\text { concentration }\end{array}$ & $\begin{array}{c}\text { Previous sampling data available } \\
\text { from ISMO study and Tank } \\
\text { Removal }\end{array}$ & $\begin{array}{l}\text { Identify current COPC } \\
\text { concentrations }\end{array}$ & $\begin{array}{l}\text { Previous analytical results can be used to } \\
\text { determine baseline conditions. } \\
\text { Assumptions about current conditions } \\
\text { can be made. }\end{array}$ \\
\hline & Potential contaminant distribution & $\begin{array}{l}\text { Location of the fuel spill is known. } \\
\text { The vertical and lateral extent of } \\
\text { COPCs was previously } \\
\text { determined. COPCs existed in } \\
\text { concentrations exceeding PALs. } \\
\text { A significant amount of time has } \\
\text { passed (approximately } 12 \text { years). } \\
\text { There is a lack of driving force due } \\
\text { to arid environment. }\end{array}$ & $\begin{array}{l}\text { Identify current vertical and lateral } \\
\text { extent of COPCs }\end{array}$ & $\begin{array}{l}\text { No additional migration of the } \\
\text { contamination after source removal is } \\
\text { expected. The vertical and lateral extent } \\
\text { of contamination are expected to have } \\
\text { decreased with natural attentuation. }\end{array}$ \\
\hline \multirow{5}{*}{$\begin{array}{l}\text { Are potential contaminants } \\
\text { migrating? }\end{array}$} & Source removal & $\begin{array}{c}\text { The source, UST DRA 22-3 was } \\
\text { removed in } 1994\end{array}$ & No data gap identified & $\begin{array}{l}\text { The source was removed. There has } \\
\text { been no additional release of } \\
\text { contamination. }\end{array}$ \\
\hline & Meteorologic data & $\begin{array}{l}\text { NTS and Yucca Mountain data on } \\
\text { annual precipitation, } \\
\text { evapotranspiration, and weather; } \\
\text { weather station present near the } \\
\text { site }\end{array}$ & $\begin{array}{l}\text { Sufficient information should be } \\
\text { available }\end{array}$ & $\begin{array}{l}\text { No site-specific meteorological data will } \\
\text { be collected; general weather conditions } \\
\text { and wind speed and direction are noted } \\
\text { on daily field notes. }\end{array}$ \\
\hline & Geologic/hydrologic data & $\begin{array}{l}\text { General geologic/hydrologic } \\
\text { characteristics of site; specific } \\
\text { geologic conditions of nearby } \\
\text { sites (i.e., CAU 342) }\end{array}$ & No data gap identified & $\begin{array}{l}\text { Geologic and hydrologic sample data will } \\
\text { be collected for this site if an investigation } \\
\text { is required. General soil characteristics } \\
\text { will be noted on sample collection log. }\end{array}$ \\
\hline & Biological degradation factors & $\begin{array}{l}\text { Hydrocarbons potentially } \\
\text { released in CAU } 329\end{array}$ & Site specific conditions unknown & $\begin{array}{l}\text { Bioassessment of similar sites may be } \\
\text { used to supplement or replace the } \\
\text { requirement to obtain additional data. }\end{array}$ \\
\hline & Radiological data & $\begin{array}{l}\text { Man-made radionuclides not } \\
\text { expected at this site }\end{array}$ & None anticipated & Not Applicable \\
\hline
\end{tabular}


Table A.4-1

Decisions, Inputs, and General Strategies

(Page 2 of 2)

\begin{tabular}{|c|c|c|c|c|}
\hline Decision & Input & Existing Data & Data Gap & Strategy \\
\hline \multirow{2}{*}{$\begin{array}{l}\text { Data sufficient to support } \\
\quad \text { closure options? }\end{array}$} & No further action & $\begin{array}{l}\text { There is historical evidence of } \\
\text { COPCs being released to the } \\
\text { environment. The horizontal and } \\
\text { vertical extent of the } \\
\text { contamination was previously } \\
\text { determined. }\end{array}$ & $\begin{array}{l}\text { Current concentration and extent } \\
\text { of COPCs }\end{array}$ & $\begin{array}{l}\text { Sufficient evidence to proceed without } \\
\text { investigation. Evaluate existing data. } \\
\text { Prepare CADD/Closure Report. }\end{array}$ \\
\hline & $\begin{array}{l}\text { Clean closure by contaminant } \\
\text { removal with bioventing }\end{array}$ & $\begin{array}{l}\text { TPH present; assume } 100 \mathrm{ppm} \text { for } \\
\text { TPH per NAC 445A. }\end{array}$ & $\begin{array}{l}\text { Current concentration and extent } \\
\text { of COPCs }\end{array}$ & $\begin{array}{l}\text { Evaluate existing data. Collect additional } \\
\text { data as required; compare results to } \\
\text { PALs. If no COPCs above PALs, } \\
\text { prepare CADD/Closure Report; } \\
\text { otherwise prepare CADD. }\end{array}$ \\
\hline
\end{tabular}

TPH - Total petroleum hydrocarbons

PRGs - Preliminary Remediation Goal(s)

NAC - Nevada Administrative Code

ppm - Parts per million

PALs - Preliminary Action Level(s)

CADD - Corrective Action Decision Document 


\section{A.5.0 Investigation Strategy}

The strategy for the CAU 329, Area 22 Desert Rock Airport Fuel Spill investigation includes conducting a soil-gas survey prior to the establishment of a DQO to determine current site conditions. The results of the survey indicated that no contamination was found in previously uncontaminated areas.

The investigation of this CAU will be as follows:

- Auger or rotary sonic drilling will be used to collect soil samples for field screening and laboratory analyses.

- If investigation is limited to shallow depths, the minimum depth of sample collection will be $20 \mathrm{ft}$ bgs. The bottom of the tank pit was approximately $16 \mathrm{ft}$ bgs. It is unknown to what depth the pit was excavated during the tank removal. It is assumed that the excavation depth was less than or equal to $20 \mathrm{ft}$. Maximum depth will be limited to $50 \mathrm{ft}$ bgs.

- If the vertical extent of contamination is to be determined, maximum depth is expected to be limited to $120 \mathrm{ft}$ bgs.

- A biased sample location will be selected at the area having the highest previous contamination. A minimum of three additional locations equally spaced around the former tank pit will be selected for investigation, if required. The exact distance from the former tank pit will be determined based on access and utility locations. The additional boreholes will be drilled to the same depth as the borehole in the source area.

- Field screen samples for the following:

- Volatile organic compounds using a photoionization detector at 10-foot intervals.

- Total petroleum hydrocarbons using the Hanby method to verify initial concentrations and at depth for the last two samples collected with field-screening results for VOCs below FSLs.

- At each sample location where COPCs are above the FSLs, the following will apply:

- Continue field screening at the next interval. If field-screening results are less than FSLs at a target depth, continue drilling an additional $10 \mathrm{ft}$; resample and field screen until two consecutive samples are below FSLs. 
- Submit a minimum of two samples for laboratory analysis. The sample with the highest field-screening result and the first of two samples with results less than FSLs.

- If COPCs are below the field-screening results for all samples for this site, a minimum of two samples will be submitted for laboratory analyses from each borehole.

- Additional samples may be collected and submitted for analyses at the discretion of the Site Supervisor.

- If COPCs extend beyond $120 \mathrm{ft}$, additional drilling may be conducted at the discretion of the Site Supervisor to a maximum depth of $200 \mathrm{ft}$.

- Perform laboratory analyses per Table A.3-1.

- If COPCs are not detected, then prepare Corrective Action Decision Document/Closure Report (CADD/CR). 


\section{A.6.0 Decision Rules}

The following decision rules shown in Table A.6-1 are applicable to the CAU 329, Area 22 Desert Rock Airport Fuel Spill, and will be used to guide the existing data evaluation and any subsequent investigation.

- If either of the following occur in the course of the investigation, then the investigation will be halted and rescoped as necessary:

- The conceptual model fails to such a degree that rescoping is required.

- Sufficient data are collected to support evaluation of corrective actions.

- If analytical results are not adequate for preparation of a CADD and/or for waste management purposes, additional sampling may be conducted and submitted for analyses at the discretion of the Site Supervisor.

- If COPCs extend beyond $200 \mathrm{ft}$, the investigation will be rescoped.

- If laboratory results indicate the presence of COPCs above PALs, a CADD will be prepared.

- If COPCs are not identified above PALs, a CADD/CR will be prepared according to the outline agreed upon by NDEP and DOE/NV. 
Table A.6-1

CAU 329 Investigation-Specific Decision Points and Rules

(Page 1 of 2)

\begin{tabular}{|c|c|c|c|}
\hline $\begin{array}{l}\text { Investigation } \\
\text { Activity }\end{array}$ & Decision Point & Decision Result & Decision Rule \\
\hline \multirow{8}{*}{$\begin{array}{l}\text { Determine current } \\
\text { contamination levels }\end{array}$} & \multirow{2}{*}{$\begin{array}{l}\text { Are current contamination } \\
\text { concentrations required? }\end{array}$} & Yes & $\begin{array}{l}\text { Collect shallow sample for TPH-Gas and TPH- Diesel Range } \\
\text { Organics analysis. }\end{array}$ \\
\hline & & No & Do not collect samples. \\
\hline & \multirow{2}{*}{$\begin{array}{l}\text { Is current vertical extent of } \\
\text { contamination required? }\end{array}$} & Yes & $\begin{array}{l}\text { Drill borehole in the vicinity of former tank pit until vertical extent } \\
\text { of contamination is determined. }\end{array}$ \\
\hline & & No & $\begin{array}{l}\text { Collect shallow samples in the vicinity of former tank pit. } \\
\text { Maximum depth is not to exceed } 50 \mathrm{ft} \text {. }\end{array}$ \\
\hline & \multirow{2}{*}{$\begin{array}{l}\text { Is the depth to the start of } \\
\text { contamination known? }\end{array}$} & Yes & $\begin{array}{l}\text { Collect first sample for field screening } 5 \mathrm{ft} \text { before expected depth } \\
\text { of contamination. Verify results with laboratory analysis. }\end{array}$ \\
\hline & & No & $\begin{array}{l}\text { Collect first sample at } 5 \mathrm{ft} \text { bgs. Collect additional samples at } 5 \mathrm{ft} \\
\text { interval for field screening. }\end{array}$ \\
\hline & \multirow{2}{*}{$\begin{array}{l}\text { Is current lateral extent of } \\
\text { contamination required? }\end{array}$} & Yes & Drill additional boreholes. \\
\hline & & No & Do not drill additional boreholes. \\
\hline \multirow{4}{*}{$\begin{array}{l}\text { Soil Sample Collection - } \\
\text { shallow }\end{array}$} & \multirow[b]{2}{*}{$\begin{array}{l}\text { Are headspace results above } \\
\text { field screening levels? }\end{array}$} & Yes & $\begin{array}{l}\text { Verify results with Hanby for first two samples only. Continue } \\
\text { investigation if less than maximum target depth. }\end{array}$ \\
\hline & & No & $\begin{array}{l}\text { Verify results with Hanby for first two samples at a depth of } 20 \mathrm{ft} \\
\text { or greater. Collect a minimum of two samples for laboratory } \\
\text { analysis within the interval } 20 \text { to } 50 \mathrm{ft} \text { bgs based on Site } \\
\text { Supervisor guidance. }\end{array}$ \\
\hline & \multirow{2}{*}{$\begin{array}{l}\text { Are Hanby results above field } \\
\text { screening levels? }\end{array}$} & Yes & $\begin{array}{l}\text { Collect sample for laboratory analysis from area with highest } \\
\text { field screening results. }\end{array}$ \\
\hline & & No & $\begin{array}{l}\text { Collect a minimum of two samples for laboratory analysis within } \\
\text { the interval } 20 \text { to } 50 \mathrm{ft} \text { bgs based on Site Supervisor guidance. }\end{array}$ \\
\hline
\end{tabular}


Table A.6-1

CAU 329 Investigation-Specific Decision Points and Rules

(Page 2 of 2)

\begin{tabular}{|c|c|c|c|}
\hline $\begin{array}{l}\text { Investigation } \\
\text { Activity }\end{array}$ & Decision Point & Decision Result & Decision Rule \\
\hline \multirow[t]{6}{*}{$\begin{array}{l}\text { Soil Sample Collection - } \\
\text { deep }\end{array}$} & \multirow[t]{2}{*}{$\begin{array}{l}\text { Did shallow samples exceed } \\
\text { FSLs? }\end{array}$} & Yes & $\begin{array}{l}\text { Continue investigation until head space field screening results } \\
\text { are below FSLs. Verify head space results with Hanby for final } \\
\text { two samples. }\end{array}$ \\
\hline & & No & $\begin{array}{l}\text { Collect a minimum of two samples for laboratory analysis based } \\
\text { on Site Supervisor guidance. }\end{array}$ \\
\hline & \multirow{2}{*}{$\begin{array}{l}\text { Are headspace results above } \\
\text { field screening levels? }\end{array}$} & Yes & Continue investigation if less than maximum target depth. \\
\hline & & No & $\begin{array}{l}\text { Collect a minimum of two samples for laboratory analysis based } \\
\text { on Site Supervisor guidance. }\end{array}$ \\
\hline & \multirow[t]{2}{*}{$\begin{array}{l}\text { Are Hanby results above field } \\
\text { screening levels? }\end{array}$} & Yes & $\begin{array}{l}\text { Continue investigation until field-screening results are below } \\
\text { FSLs. }\end{array}$ \\
\hline & & No & $\begin{array}{l}\text { Collect a minimum of two samples for laboratory analysis based } \\
\text { on Site Supervisor guidance. }\end{array}$ \\
\hline
\end{tabular}




\section{A.7.0 Decision Error}

A biased sampling location will be selected in the vicinity of the former tank pit. The sampling strategy targets the worst-case contamination by directly sampling areas where previous sampling has shown high levels of contamination. This sampling strategy will reduce the possibility of missing contamination and will yield the highest confidence that the extent of contamination, if present, has been adequately bounded. Selected samples will be sent to an off-site laboratory for analyses using the rational in Sections A.5.0 and A.6.0. of this appendix. 


\section{A.8.0 References}

Coordinating Research Council, Inc. 1988. Aviation Fuel Properties, CRC Report No. 530, May. Atlanta, GA.

DOE, see U.S. Department of Energy.

DOE/NV, see U.S. Department of Energy, Nevada Operations Office.

EG\&G/EM, see EG\&G Energy Measurements.

EPA, see U.S. Environmental Protection Agency.

EG\&G Energy Measurements. 1991. Aerial photographs NF-13076 and 6991-128 and ground-level photographs NF-3986 and NF-8155. Nellis Air Force Base, NV: Remote Sensing Laboratory Photo Library.

Holmes \& Narver, Inc. 1986. Nevada Test Site Development Plan, Part II, May. Prepared for the U.S. Department of Energy, Nevada Operations Office. Las Vegas, NV.

IT Corporation. 1998. Project Files for CAU 329, CAS 22-44-01. Includes field activity daily logs, field forms, Geographic Positioning System coordinates, photodocumentation forms, and checkprints. Also included is a Spill Notification Report prepared by BN. Las Vegas, NV.

NAC, see Nevada Administrative Code.

Nevada Administrative Code. 1998. NAC445A.345 - 445A.22755, "Corrective Action Regulations." Carson City, NV: Nevada Division of Environmental Protection.

Reynolds Electrical \& Engineering Co., Inc. 1991. The Nevada Test Site Application of In Situ Monitoring of Organics at a Jet-A Fuel Spill, DOE/NV/10630-12, January. Prepared by B. Dozier and D. Emer. Las Vegas, NV.

Reynolds Electrical \& Engineering Co., Inc. 1994. Memo from D. Madsen to Ken Hoar (DOE/NV) entitled, "Work Request - Disposal of Area 22 Desert Rock Airstrip Underground Storage Tank (UST) Number 22-DRA-3 Hydrocarbon Impacted Soil,” 6 September. Las Vegas, NV.

Reynolds Electrical \& Engineering Co., Inc. 1994. NTS Underground Storage Tank Status List, 9 November. Las Vegas, NV.

U.S. Department of Energy. 1988. Environmental Survey Preliminary Report Nevada Test Site, Mercury, Nevada. Washington, DC: Environment, Safety and Health Office of Environmental Audit. 
U.S. Department of Energy, Nevada Operations Office. 1992. RCRA Part B Permit Application for Waste Management Activities at the Nevada Test Site, July, Volume IV, Section L. Las Vegas, NV.

U.S. Department of Energy, Nevada Operations Office. 1994. Interoffice memo from P. Sanders to B. Yoerg (DOE/NV) entitled, "Desert Rock Airstrip UST Release," 9 March. Las Vegas, NV: Environmental Protection Division.

U.S. Department of Energy, Nevada Operations Office. 1996. Final Environmental Impact Statement for the Nevada Test Site and Off-Site Locations in the State of Nevada, DOE/EIS 0243. Las Vegas, NV.

U.S. Environmental Protection Agency. 1996. Test Methods for Evaluating Solid Waste, Physical/Chemical Methods, SW-846, Third Edition, CD ROM, PB97-501928GEI. Washington, DC. 
Appendix B

\section{Project Organization}




\section{B.1.0 Project Organization}

The DOE/NV Industrial Sites Project Manager is Janet Appenzeller-Wing and her telephone number is (702) 295-0461.

The identification of the project Health and Safety Officer and the Quality Assurance Officer can be found in the appropriate DOE/NV plan. However, personnel are subject to change and it is suggested that the Project Manager be contacted for further information. The Task Manager will be identified in the FFACO Biweekly Activity Report prior to the start of field activities. 


\section{Appendix C}

\section{Response to NDEP Comments}




\section{NEVADA ENVIRONMENTAL RESTORATION PROJECT}

DOCUMENT REVIEW SHEET

(Page 1 of 6)

\begin{tabular}{|c|c|c|c|c|c|}
\hline \multicolumn{4}{|c|}{$\begin{array}{l}\text { 1. Document Title/Number: Draft Streamlined Approach for Environmental Restoration Work Plan for Corrective } \\
\text { Action Unit 329: Area } 22 \text { Desert Rock Airstrip Fuel Spill, Nevada Test Site, Nevada }\end{array}$} & \multicolumn{2}{|l|}{ 2. Document Date: July 1999} \\
\hline \multicolumn{4}{|c|}{ 3. Revision Number: 0} & \multicolumn{2}{|c|}{ 4. Originator/Organization: IT Corporation } \\
\hline \multicolumn{4}{|c|}{ 5. Responsible DOE/NV ERP Project Mgr.: Janet Appenzeller-Wing } & \multicolumn{2}{|l|}{ 6. Date Comments Due: } \\
\hline \multicolumn{6}{|c|}{ 7. Review Criteria: Full } \\
\hline \multicolumn{4}{|c|}{ 8. Reviewer/Organization/Phone No.: David P. Friedman, NDEP, 486-2856 } & \multicolumn{2}{|l|}{ 9. Reviewer's Signature: } \\
\hline $\begin{array}{l}\text { 10. Comment } \\
\text { Number/ } \\
\text { Location }\end{array}$ & 11. Type* & 12. Comment & & 3. Comment Response & 14. Accept \\
\hline $\begin{array}{l}\text { 1) Executive } \\
\text { Summary, } \\
\text { Page ES-1, } \\
4^{\text {th }} \text { Bullet }\end{array}$ & & $\begin{array}{l}\text { Correct the typographical error "...(if on usable)..." Parenthetical } \\
\text { phrase should read (if unusable). }\end{array}$ & \multicolumn{2}{|c|}{ The typographical error has been corrected. } & Yes \\
\hline $\begin{array}{l}\text { 2) Executive } \\
\text { Summary, } \\
\text { Page ES-1, } \\
4^{\text {th }} \text { Bullet and } \\
\text { Section } 1.0 \text {, } \\
\text { Page } 3,4^{\text {th }} \text { Bullet }\end{array}$ & & $\begin{array}{l}\text { NDEP believes it is inappropriate to predetermine the soil-vapor } \\
\text { sampling points, if a new monitoring well for soil-vapor sample } \\
\text { extraction has to be installed at DRA. NDEP accepts these sample } \\
\text { points as a matter of efficient resource allocation to utilize the } \\
\text { existing monitoring well DRA-3. However, if DRA-3 should be found } \\
\text { to be unusable in the spill remediation field work, the sampling } \\
\text { points of the new monitoring well should incorporate the new data } \\
\text { collected to identify the most appropriate locations to monitor the } \\
\text { fuel spill's biodegradation. }\end{array}$ & \multicolumn{2}{|c|}{$\begin{array}{l}\text { The text has been changed to read "... at appropriate depths } \\
\text { below the ground surface as determined during the } \\
\text { investigation and as approved by the U.S. Department of } \\
\text { Energy, Nevada Operations Office and the Nevada Division } \\
\text { of Environmental Protection." }\end{array}$} & Yes \\
\hline $\begin{array}{c}\text { 3) Section 1.0, } \\
\text { Page 1, } \\
\text { Introduction }\end{array}$ & & $\begin{array}{l}\text { An important element of the SAFER process is the identification of } \\
\text { decision points where DOE will reach consensus with NDEP prior to } \\
\text { beginning the next phase of activity. Nowhere in the discussion of } \\
\text { the SAFER process of this text or in the flowchart discussed below } \\
\text { does it indicate that NDEP will be conferred with before proceeding. } \\
\text { DOE needs to re-write this section to include these important project } \\
\text { junctures. }\end{array}$ & \multicolumn{2}{|c|}{$\begin{array}{l}\text { Figure } 1-2 \text { and Section } 3.2 \text { have been modified to include } \\
\text { DOE and NDEP approval. }\end{array}$} & Yes \\
\hline
\end{tabular}




\section{NEVADA ENVIRONMENTAL RESTORATION PROJECT}

DOCUMENT REVIEW SHEET

(Page 2 of 6$)$

\begin{tabular}{|c|c|c|c|c|}
\hline $\begin{array}{l}\text { 10. Comment } \\
\text { Number/ } \\
\text { Location }\end{array}$ & 11. Type* & 12. Comment & 13. Comment Response & 14. Accept \\
\hline $\begin{array}{l}\text { 4) Section 1.0, } \\
\text { Page } 4 \text {, } \\
\text { Figure } 1-2\end{array}$ & & $\begin{array}{l}\text { The decision point sampling interval located in the second tier } \\
\text { decision block "..Drill Borehole through center of spill..." is indicated } \\
\text { as sample every twenty feet. This sample frequency does not } \\
\text { concur with that stated in Section } 3.0 \text { Field Activities, page 11, first } \\
\text { bullet, which is defined as "...two- to five-ft. depth intervals within the } \\
\text { borehole..." }\end{array}$ & $\begin{array}{l}\text { The text in Section } 3.0 \text { Field Activities has been changed to } \\
\text { read "at } 20 \text {-ft intervals". }\end{array}$ & Yes \\
\hline $\begin{array}{l}\text { 5) Section 1.0, } \\
\text { Page 4, } \\
\text { Figure 1-2 } \\
\text { (CONTINUED) }\end{array}$ & & $\begin{array}{l}\text { The decision point on the third tier decision block "... Have } 2 \\
\text { consecutive samples been }<100 \text { ppm soil-vapor..." is too vague. It } \\
\text { is stated in the report that the tank was installed to a depth of } 16 \mathrm{ft} \text {. } \\
\text { bgs and was removed in } 1994 \text {. It is not stated as to how the tank } \\
\text { excavation was backfilled, but it is indicated in the report that at least } \\
\text { some (east-side soil pile) of the excavated hydrocarbon-burdened } \\
\text { soil was disposed of offsite. It is therefore reasonable to presume } \\
\text { that the upper } 16 \mathrm{ft} \text { of material at the former tank location will have } \\
\text { values less than } 100 \mathrm{ppm} \mathrm{TPH} \mathrm{in} \mathrm{the} \mathrm{soil} \mathrm{vapor.} \mathrm{Based} \mathrm{on} \mathrm{this} \mathrm{and} \\
\text { the scoped sample frequency of two- to five-ft., it is possible to } \\
\text { decide to end the soil boring before the bottom of the tank } \\
\text { excavation has been reached. Furthermore, the plot plan of the } \\
\text { aircraft fuel system (Holmes \& Narver, Drawing } \\
\text { No. JS-022-081-M1.1) supplied to NDEP during the DQO meeting } \\
\text { does not indicate the elevations of the approximately } 100 \text { linear feet } \\
\text { of } 3 \text { " diameter underground supply piping at the tank end or } \\
\text { dispensary end. As this piping was sealed and left in place, it is } \\
\text { reasonable to assume that product could have remained in the pipe } \\
\text { and if the piping was compromised, additional product could have } \\
\text { drained back down to the former tank location. NDEP would like to } \\
\text { see the planned soil boring proceed to a minimum depth of } 120 \mathrm{ft} \text {., } \\
\text { which is the ISMO study limit of the wetting-front. }\end{array}$ & $\begin{array}{l}\text { The sample frequency has been changed to a } 20 \text {-ft interval. } \\
\text { This will ensure that a minimum of two samples will be } \\
\text { collected from native materials below the former tank pit. } \\
\text { The planned minimum boring depth has been changed to } \\
120 \mathrm{ft} \text {. } \\
\text { The piping was last used in } 1990 \text {. The tank was last used in } \\
1993 \text { and was removed in } 1994 \text {. The outlet from the pump } \\
\text { to the separator was approximately } 3 \mathrm{ft} \text { bgs. The amount of } \\
\text { residual product in the piping is expected to be minimal. The } \\
\text { volume of } 100 \mathrm{ft} \text { of } 3 \text { in. pipe is } 4.9 \mathrm{ft}^{3} \text { or approximately } 37 \\
\text { gallons. All of these factors would result in a minimal } \\
\text { additional impact at the site if there was any remaining } \\
\text { product in the piping system. }\end{array}$ & Yes \\
\hline
\end{tabular}




\section{NEVADA ENVIRONMENTAL RESTORATION PROJECT}

\section{DOCUMENT REVIEW SHEET}

(Page 3 of 6)

\begin{tabular}{|c|c|c|c|c|}
\hline $\begin{array}{l}\text { 10. Comment } \\
\text { Number/ } \\
\text { Location }\end{array}$ & 11. Type* & 12. Comment & 13. Comment Response & 14. Accept \\
\hline $\begin{array}{l}\text { 6) Section } 1.0 \\
\text { Page } 4 \\
\text { Figure } 1-2 \\
\text { (CONTINUED) }\end{array}$ & & $\begin{array}{l}\text { Correct the inconsistencies with the decision block on the fourth tier } \\
\text { "...Is depth greater than } 200 \text { feet bgs?..." The maximum depth of the } \\
\text { soil boring is stated to be less than or equal to } 200 \mathrm{ft} \text {. in this work } \\
\text { plan scope and } 200 \mathrm{ft} \text {. is not an appropriate decision point. The } \\
\text { previous ISMO study indicated the depth of } 100 \mathrm{ppm} \text { action level } \\
\text { exceedance to be approximately } 160 \mathrm{ft} . ; \text { therefore, } 160 \mathrm{ft} \text {. is the } \\
\text { conservative level at which to branch a decision point. If the soil } \\
\text { boring reaches a depth of } 160 \mathrm{ft} \text {. and soil-vapor samples are at or } \\
\text { below the } 100 \mathrm{ppm} \text { action level, then the no branch of this decision } \\
\text { block should direct the decision maker to discontinue the boring, not } \\
\text { return the decision maker back to "...Drill Borehole through center of } \\
\text { spill..... If the soil boring has reached the } 160 \mathrm{ft} \text {. depth and action } \\
\text { levels are in exceedance of } 100 \text { ppm TPH, the yes branch needs to } \\
\text { direct the decision maker to continue the boring to plan depth } \\
\text { (200 ft.) and determine whether the trend has indicated a decrease } \\
\text { in soil-vapor TPH levels. }\end{array}$ & $\begin{array}{l}\text { The investigation depth has been changed to a minimum } \\
\text { depth of } 120 \mathrm{ft} \text { and a maximum depth of } 200 \mathrm{ft} \text {. The depth of } \\
\text { the wetting front migration was determined to be } 120 \mathrm{ft} \text { in the } \\
\text { ISMO study. It is believed that this is a reasonable depth to } \\
\text { select as a minimum required investigation. } \\
\text { The maximum depth that soil-vapors exceeded the action } \\
\text { level was } 160 \mathrm{ft} \text {. It is believed that continuing to } 200 \mathrm{ft} \text { is a } \\
\text { conservative decision. }\end{array}$ & Yes \\
\hline $\begin{array}{l}\text { 7) Section } 1.0 \\
\text { Page } 4 \\
\text { Figure } 1-2 \\
\text { (CONTINUED) }\end{array}$ & & $\begin{array}{l}\text { NDEP needs explanation as to what the technical basis is for the } \\
\text { decision point in the fifth tier. The action level referred to is the } \\
\text { decision point to initiate active bioremediation effort if the soil-vapor } \\
\text { is } 10,000 \mathrm{ppm} \text { TPH. }\end{array}$ & $\begin{array}{l}\text { The text has been changed to reflect EPA guidance for } \\
\text { natural attenuation is most effective for TPH concentrations } \\
\text { less than } 25,000 \mathrm{ppm} \text {. }\end{array}$ & Yes \\
\hline $\begin{array}{l}\text { 8) Section } 1.0 \\
\text { Page } 4 \\
\text { Figure } 1-2 \\
\text { (CONTINUED) }\end{array}$ & & $\begin{array}{l}\text { At several of the decision point blocks, it is stated that decisions will } \\
\text { be based on field screening and laboratory analysis. This leads to } \\
\text { numerous problems, including potential discrepancy between field } \\
\text { screening and laboratory analytical results and the time delay } \\
\text { between field screening and laboratory analysis. DOE needs to } \\
\text { propose making decisions on one or the other method, and NDEP } \\
\text { will comment on the appropriateness of the method with respect to } \\
\text { the specific decision. }\end{array}$ & $\begin{array}{l}\text { The text has been changed to read that decisions will be } \\
\text { made based on field screening. Samples will be submitted } \\
\text { for laboratory analysis for verification. }\end{array}$ & Yes \\
\hline
\end{tabular}




\section{NEVADA ENVIRONMENTAL RESTORATION PROJECT}

DOCUMENT REVIEW SHEET

(Page 4 of 6)

\begin{tabular}{|c|c|c|c|c|}
\hline $\begin{array}{l}\text { 10. Comment } \\
\text { Number/ } \\
\text { Location }\end{array}$ & 11. Type* & 12. Comment & 13. Comment Response & 14. Accept \\
\hline $\begin{array}{l}\text { 9) Section } 2.4 \text {, } \\
\text { Page } 8 \text {, Closure } \\
\text { Standards }\end{array}$ & & $\begin{array}{l}\text { The SAFER plan allows for closure to proceed simultaneously with } \\
\text { site characterization and remediation, with adjustments made to the } \\
\text { closure plan as data generated from characterization and/or } \\
\text { remediation validates or contradicts initial assumptions. Therefore, } \\
\text { DOE needs to present quantifiable limits in this section which define } \\
\text { the DOE's commitment to monitoring the intrinsic bioremediation } \\
\text { process and verify the point at which closure has been attained. It is } \\
\text { also significant to note that Nevada regulations for clean-up of } \\
\text { petroleum spills are based on TPH levels in the soil, but DOE is } \\
\text { proposing action levels here based on soil-vapor gas levels. Where } \\
\text { the soils have been saturated by the petroleum hydrocarbons due to } \\
\text { the spill, these soil-vapor levels may not accurately indicate the } \\
\text { actual TPH levels. But if the wetting-front has stabilized and the } \\
\text { petroleum hydrocarbons are continuing to migrate downward by } \\
\text { diffusion as denser vapors in the soil-gas, the soil-gas TPH may } \\
\text { inaccurately overestimate the TPH levels in the soil. NDEP needs } \\
\text { to understand how DOE is correlating the TPH soil-gas levels to the } \\
\text { TPH soil levels. }\end{array}$ & $\begin{array}{l}\text { All references to action levels have been changed to ppm } \\
\text { not ppmv. } \\
\text { The requirement for evaluating the NAC } 459.9973 \text { factors } \\
\text { will be based on analytical results from soil samples } \\
\text { collected during the investigation. Soil-gas samples will also } \\
\text { be collected at the same time for a correlation of current } \\
\text { conditions. Future monitoring of the site will be done using } \\
\text { soil-gas samples. An estimated soil TPH level will be } \\
\text { determined for future monitoring events based on initial soil } \\
\text { to soil-gas ratios. }\end{array}$ & Yes \\
\hline
\end{tabular}


NEVADA ENVIRONMENTAL RESTORATION PROJECT

DOCUMENT REVIEW SHEET

(Page 5 of 6$)$

\begin{tabular}{|c|c|c|c|c|}
\hline $\begin{array}{l}\text { 10. Comment } \\
\text { Number/ } \\
\text { Location }\end{array}$ & 11. Type* & 12. Comment & 13. Comment Response & 14. Accept \\
\hline $\begin{array}{l}\text { 10) Section } 3.0 \\
\text { Page } 10, \text { Field } \\
\text { Activities }\end{array}$ & & $\begin{array}{l}\text { As a general comment and stated above in association to } \\
\text { Figure 1-2, NDEP found this section to be lacking many essential } \\
\text { elements as required by the SAFER process. The proposed field } \\
\text { work is inadequately described here. NDEP was left with numerous } \\
\text { questions after reading this section with regard to the technical } \\
\text { adequacy and appropriateness of the methodology DOE contractors } \\
\text { would use in order to accomplish the described tasks. For example, } \\
\text { what method of drilling is being proposed for the soil boring. NDEP } \\
\text { would like technical verification that if an air-rotary method such as } \\
\text { ODEX is used, soil-vapor samples collected will not be effected by } \\
\text { the compressed air introduced in the borehole to remove the } \\
\text { cuttings. NDEP needs to understand how the soil-vapor samples } \\
\text { will be collected. It appears as DOE is proposing to stop drilling at } \\
\text { each two-foot interval, remove the drill steel from the hole, and } \\
\text { collect a soil-vapor sample from the boring. NDEP does not } \\
\text { understand the sampling program being proposed. There are } \\
\text { inconsistencies between the flowchart and what is stated here. The } \\
\text { entire field work program being proposed needs to be clearly } \\
\text { detailed in this section, or NDEP can not approve of DOE moving } \\
\text { forward. }\end{array}$ & Details of the field investigation were added. & Yes \\
\hline $\begin{array}{l}\text { 11) Section } 3.2 \text {, } \\
\text { Page } 11, \\
\text { Contaminants of } \\
\text { Potential Concern }\end{array}$ & & $\begin{array}{l}\text { NDEP found this section deficient in defining the COPCs and the } \\
\text { methodology to be used in analyzing for them in the two proposed } \\
\text { media to be sampled (soil and soil-gas vapor). Section } 3.3 \\
\text { Verification states that in addition to TPH as gasoline and kerosene } \\
\text { (JP-4), soil samples will be submitted for laboratory analyses of } \\
\text { VOCs and SVOCs. In addition, Section } 3.3 \text { states that soil samples } \\
\text { will be field screened for plutonium and uranium using alpha } \\
\text { spectroscopy. Therefore, all those COPCs need to be identified. }\end{array}$ & $\begin{array}{l}\text { The analytical requirements for the COPCs was clarified. } \\
\text { All references to plutonium and uranium and associated } \\
\text { analytical methods have been deleted from the document. }\end{array}$ & Yes \\
\hline $\begin{array}{l}\text { 12) Section } 3.2 \text {, } \\
\text { Page } 11 \text {, } \\
\text { Remediation }\end{array}$ & & $\begin{array}{l}\text { Intrinsic bioremediation may be a passive form of remediation, but it } \\
\text { is recognized by NDEP and USEPA as a form of remediation. } \\
\text { Therefore, this section needs to define the monitoring program } \\
\text { proposed by DOE which will track the progress of the remediation } \\
\text { effort and when monitoring can be discontinued. }\end{array}$ & $\begin{array}{l}\text { Details of the monitoring requirements have been added in } \\
\text { Section 3.3. }\end{array}$ & Yes \\
\hline
\end{tabular}




\section{NEVADA ENVIRONMENTAL RESTORATION PROJECT}

DOCUMENT REVIEW SHEET

(Page 6 of 6)

\begin{tabular}{|c|c|c|c|c|}
\hline $\begin{array}{l}\text { 10. Comment } \\
\text { Number/ } \\
\text { Location }\end{array}$ & 11. Type* & 12. Comment & 13. Comment Response & 14. Accept \\
\hline $\begin{array}{l}\text { 13) Section } 3.3 \\
\text { Page } 11 \\
\text { Verification }\end{array}$ & & $\begin{array}{l}\text { Provide discussion here as to what analytical levels will define that } \\
\text { adequate intrinsic bioremediation is proceeding without additional } \\
\text { activation. These proposed levels should be for both the soil-vapors } \\
\text { extracted from monitoring well DRA-3 (or its replacement, if } \\
\text { necessary) and in the totals detected from the soil samples } \\
\text { collected. The levels proposed should have some connection to the } \\
\text { depth from which they were collected, as this is an important } \\
\text { consideration as to whether the spill has stabilized or continues to } \\
\text { advance. Also, add TPH kerosene (or JP-4) to the list of COPCs to } \\
\text { be analyzed for in the laboratory samples. }\end{array}$ & $\begin{array}{l}\text { The details of the proposed verification methods have been } \\
\text { added in Section 3.3. }\end{array}$ & Yes \\
\hline $\begin{array}{l}\text { 14) Section } 3.4 \text {, } \\
\text { Page } 11, \text { Closure }\end{array}$ & & $\begin{array}{l}\text { Provide discussion here as to what levels need to be attained to } \\
\text { achieve closure and how those levels will be verified. }\end{array}$ & The closure requirements were clarified. & Yes \\
\hline $\begin{array}{l}\text { 15) Section } 3.5 \\
\text { Page } 12 \\
\text { Duration }\end{array}$ & & $\begin{array}{l}\text { Provide in this section not just an estimation of how long field } \\
\text { characterization activities will take, but also how long DOE believes } \\
\text { it will take to achieve closure. If an estimate of the time to achieve } \\
\text { closure is technically nonfeasible, then provide recognition of the } \\
\text { fact and assure that the site will be monitored to confirm that intrinsic } \\
\text { bioremediation continues to progress. }\end{array}$ & $\begin{array}{l}\text { If evaluation of NAC } 459.9973 \text { factors indicates that } \\
\text { corrective action will be required at CAU } 329 \text {, the site will be } \\
\text { monitored for five years to determine the natural attenuation } \\
\text { rate. Any additional activities required for closure of the site } \\
\text { will be determined at that time. }\end{array}$ & Yes \\
\hline $\begin{array}{l}\text { 16) Section } 5.3 .3 \\
\text { Page } 15 \\
2^{\text {nd }} \text { Paragraph, } \\
\text { Lines } 13 \& 15\end{array}$ & & $\begin{array}{l}\text { Correct the typographical error "...These analysis..." and "...The } \\
\text { analysis are required..." } \\
\text { The correct word in both these sentences is analyses. }\end{array}$ & The entire paragraph was deleted from the document. & Yes \\
\hline
\end{tabular}

${ }^{a}$ Comment Types: $M=$ Mandatory, $S=$ Suggested

Return Document Review Sheets to DOE/NV Environmental Restoration Division, Attn: QAC, M/S 505. 


\section{Distribution}

*Provide copy in distribution of Revision 0 and subsequent revisions, if applicable. Copies of only the NDEP-approved document will be distributed to others.

Paul J. Liebendorfer

State of Nevada

Bureau of Federal Facilities

Division of Environmental Protection

333 W. Nye Lane, Room 138

Carson City, NV 89706-0851

Michael McKinnon

State of Nevada

Bureau of Federal Facilities

Division of Environmental Protection

555 E. Washington, Suite 4300

Las Vegas, NV 89101

Sabrina Lawrence

Environmental Restoration Division

DOE/Nevada Operations Office

P.O. Box 98518, M/S 505

Las Vegas, NV 89193-8518

Janet Appenzeller-Wing

Environmental Restoration Division

DOE/Nevada Operations Office

P.O. Box 98518, M/S 505

Las Vegas, NV 89193-8518

Clayton Barrow

Environmental Restoration Division

DOE/Nevada Operations Office

P.O. Box 98518, M/S 505

Las Vegas, NV 89193-8518

Wayne Johnson

Bechtel Nevada

P.O. Box 98521, M/S NTS306

Las Vegas, NV 89193-8521
2 (Controlled)*

1 (Controlled)*

1 (Controlled)*

1 (Uncontrolled)*

1 (Uncontrolled)*

1 (Uncontrolled)* 
Jerry Bonn

Bechtel Nevada

P.O. Box 98521, M/S NTS306

Las Vegas, NV 89193-8521

IT Corporation Central Files

P.O. Box 93838

Las Vegas, NV 89193

Jeff Johnson

IT Corporation

P.O. Box 93838

Las Vegas, NV 89193

Dustin Wilson

SAIC

P.O. Box 93838

Las Vegas, NV 89193

Bob McCall

SAIC

P.O. Box 93838

Las Vegas, NV 89193

Technical Information Resource Center

DOE/Nevada Operations Office

IT Corporation

P.O. Box 93838

Las Vegas, NV 89193

U.S. Department of Energy

Office of Scientific and Technical Information

P.O. Box 62

Oak Ridge, TN 37831

Manager Southern Nevada FFACO

Public Reading Room

P.O. Box 98521, M/S NLV040

Las Vegas, NV 89193-8521
1 (Uncontrolled)*

1 (Uncontrolled)*

1 (Uncontrolled)*

1 (Uncontrolled)*

1 (Uncontrolled)*

1 (Uncontrolled)

1 (Uncontrolled, electronic copy)

1 (Controlled)*

1 (Uncontrolled)* 
Manager Northern Nevada FFACO

Public Reading Room

c/o Rosa Silver

IT Corporation

P.O. Box 93838

Las Vegas, NV 89193

FFACO Public Reading Rooms Coordinator

Rosa Silver

IT Corporation

P.O. Box 93838

Las Vegas, NV 89193

Earl Dixon

Community Advisory Board

UNLV, Harry Reid Center for Environmental Studies 4505 S. Maryland Pkwy

Las Vegas, NV 89154

H. Ray Johnson

Community Advisory Board

9642 Hawaiian Summer St.

Las Vegas, NV 89123
1 (Uncontrolled)*

1 (Controlled)*

1 (Uncontrolled)*

1 (Uncontrolled)* 